\title{
Literary-Historical Influences
}

on the Novels of Sarah Waters

By

\section{Rae Robinson}

\begin{abstract}
A Thesis
Submitted to the Victoria University of Wellington

In Fulfilment of the Requirements for the Degree of

Master of Arts

in English Literature
\end{abstract}

School of English, Theatre, Film \& Media Studies

Victoria University of Wellington

2008 


\section{$\underline{\text { Abstract }}$}

In this thesis I examine the influences on the historical novels of Sarah Waters. Waters uses multiple sources from the Victorian literary tradition to construct her novels and displays an awareness of recent trends in scholarship in selecting those sources. Waters uses conventions that were popular with Victorian readers and updates them for a contemporary audience, by focusing, for example, on gay and lesbian characters and on sexuality. 


\section{Contents}

Introduction

Tipping the Velvet 2

$\begin{array}{ll}\text { Conclusion } & 13\end{array}$

$\begin{array}{lc}\text { Endnotes } & 13\end{array}$

$\begin{array}{lr}\text { Affinity } & 14\end{array}$

$\begin{array}{lr}\text { Conclusion } & 27\end{array}$

$\begin{array}{ll}\text { Endnotes } & 27\end{array}$

$\begin{array}{ll}\text { Fingersmith } & 28\end{array}$

Conclusion 43

$\begin{array}{ll}\text { Endnotes } & 44\end{array}$

The Night Watch 45

$\begin{array}{lr}\text { Conclusion } & 58\end{array}$

$\begin{array}{lr}\text { Endnotes } & 59\end{array}$

$\begin{array}{ll}\text { Works Cited } & 60\end{array}$

Bibliography 


\section{Introduction}

What are the influences on the novels of Sarah Waters? This is the question I will be examining in this thesis. Waters uses multiple sources from the Victorian literary tradition to construct her novels and displays an awareness of recent trends in scholarship in selecting those sources. As Wheeler writes in English Fiction of the Victorian Period 1830-1890, "Victorian Literature is characteristically a mixed genre" $(1985,7)$. It comprises elements of melodrama, sensation, the gothic and social realism. Each of Waters' novels, Tipping the Velvet (1998), Affinity (1999), Fingersmith (2002), which are all set in the Victorian period, and The Night Watch (2006) which is set in WWII, reflect these influences. The Night Watch, which was nominated for the Booker Prize, is influenced not only by the society and literature of WWII, but by that of the Victorian era, a potentially risky hybrid which displays Waters' expert handling of the conventions of each.

The historical novel has in the past been a low culture popular genre. There is a big difference between a novel by Victorian writer Charles Dickens and a historical novel set in the Victorian period. Philipa Gregory, author of The Other Boleyn Girl, is the typical writer of popular historical fiction- what might be termed the airport historical novel, which does not use the conventions of the historical fiction of the era it portrays and does not necessary display a detailed depth of historical awareness. Waters' historical novels are different to Gregory's because of the depth of her scholarship. Waters has a Ph.D. in Victorian literature and has been a lecturer with the Open University (Velvet, frontispiece). Nevertheless, her novels have had commercial success as well as critical acclaim, because she uses conventions that were popular with Victorian readers and updates them for a contemporary audience, by focusing, for example, on gay and lesbian characters and on sexuality. There is a possibility Waters may influence a renewal of popular historical novel away from its stale generalisations and formats. 
Tipping The Velvet: "A double act is always twice the act the audience thinks it".

Waters first novel, Tipping the Velvet (1998), is primarily set in the Victorian theatre world and sexual underworld. Its heroine, Nan Astley, is an oyster-girl from Whitstable. Nan meets actress Kitty Butler at the local theatre, is hired as her dresser, and goes to London, where she lives in a relationship with Kitty and becomes an actress in their double act. The relationship ends when Kitty has an affair with their manager, Walter Bliss, and Nan runs away to become a prostitute and kept woman, eventually being rescued and falling in love with social worker Florence Banner.

Narrator-Heroine Nan Astley undergoes a series of transformations. The way that Waters tells the story is influenced by fairy-tale and the gothic. The transformations reflect the speed of change in an insecure Victorian society and the way that its sordid truths are cloaked by respectability. Nan's role develops from provincial kitchen hand with a boyfriend, to actress Kitty Butler's assistant, to cross-dressing London theatre performer and Kitty's lover, to street prostitute, then kept woman of aristocratic Diana Lethaby, and finally, saved woman, and housemaid, assisting new girlfriend Florence's good works.

Nan's journey to adulthood involves transformation. This is a coming of age story, or bildungsroman, which uses narrative archetypes and fairy-tale plotting. Nan is a small town working class girl who runs away to London, for love, fame and fortune, similar to Dick Wittington. Nan describes herself as plain, in contrast to sister Alice's beauty (Velvet, 7-8), which sets the scene for her ugly duckling to swan transformation. When Kitty throws a flower at her from the stage the Sleeping Beauty awakes: "When you threw this to me... my life changed. I think I must have been asleep - till that moment: asleep, or dead. Since I met you, I've been awake - alive!” (55-6). Kitty compares Nan to a "mermaid" (33). Nan imagines their fairy-tale home in London: "Grease-Paint Avenue! ... a street set out like a make- up box, with narrow gilded houses, each one with a different coloured roof..." (61). Kitty is worthy of mythical deeds: "And there was nothing you would not do...not sacrifice, to keep your hearts desire..." (72). Nan's new dress “was made just for you, like Cinderella's 
slipper" (93) and "so transforming it was practically a disguise" (94). The dress makes Nan feel like the grown up woman she now realises she is (95). Her transformation attracts male attention and she incurs Kitty's jealousy as "Miss Flirt" (98).

Nan typifies the Victorian age, transforming to suit her society and surroundings. Her transformation symbolises provincial-urban drift. Her fingers, once pink and puckered from working with oysters are now yellow with tobacco (95). London itself transforms into a fairytale place. Nan narrates a magical journey through the London night: "Beside us the pavements glittered with frost, and each street - lamp glowed in the fog, from the centre of its own yellow nimbus...the driver, Kitty and I might have been the only wakeful creatures in a city of stone and ice and slumber" (101). This “transformation...seemed a little miracle, done just for Kitty and me. ... I saw us floating down the Thames, out to sea - past Whitstable, perhaps - on a piece of ice no bigger than a pancake" (102).

Names suggest transformation: Walter Bliss is not the real name of Nan and Kitty's manager, he is from a theatrical family. He is also "Walter Waters, Character Baritone" (65). And "even the dog, Bransby, ... had a stage name: Archie" (75). Nan is offered a cornucopia of stage names to try on like "marvellous...jackets" (125).

The position of women within society slowly became less restricted during the Victorian era. The transformation of women is underlined: "“Four months ago I was an oyster-girl in Whitstable!' 'Four months before, Bessie Bellwood made her debut', Walter replied, 'she was a rabbit-skinner..."' (113). In the tailor's shop, Nan becomes "a boy with buttons and a belt" (118).

The transformations in the story and Nan's position in it appear less in her favour. It is as if the fairy-tale is out of Nan's control. When Nan and Kitty leave Mrs Dendys' due to money and respectability issues, Nan “wished I could be plain Nancy Astley again, whom Kitty Butler loved with an ordinary love she was not afraid to show all the world" (144-5). But the heart of the fairytale is empty. As Kitty dresses as a man on stage and as a woman off it, Nan has 
apparently found in her both her fairytale princess and prince whom she worships as glamorous and brave and whom she has modelled herself and her career on. However, in the process of her initially reluctant stage career, Nan herself becomes a fairy prince/ss, transformed by new confidence and the stardust of celebrity into an icon for fans. Kitty is Cinderella's Prince, in a West End theatre. Nan only plays the fool who brings Cinderella the slipper (148). This is an omen that Nan's fairy-tale will not last. Nan's notion of family changes from her biological family to strangers and the Brit Theatre becomes her new family, as Mrs Dendy's was (140). However, homesick Nan rediscovers a map which her brother Davy "marked with a faded arrow", like a treasure map: "To show me where home was, in case I forgot" and she briefly returns (151). Kitty claims: "I should never have taken you away from Whitstable Bay, Miss Mermaid" (152), which is one of Nan's fairytale roles, which has a prosaic genesis in shelling oysters for her family's business. At Whitstable things appear to have changed for the worse, possibly due to Nan's altered perception (154). Her accent has transformed: "all lardy-dah" (155). The expensive gifts she bought for family transform into "trash"(157). Nan can no longer help with the oysters as it now hurts her fingers (163). She now perceives the bill at the Canterbury Palace as "second-rate" (164). She returns to London, and it is then that her fairytale relationship with Kitty falls apart, as she is supplanted by another, evil, fairytale prince, the girls' manager, Walter Bliss.

It is now that Nan undergoes her darkest transformations. Running from Walter and Kitty on discovering their affair, Nan dresses as a boy and becomes an apparently male prostitute (197). Like a Persian tale about a beggar who is offered a princess, she is offered a brief life of luxury as Diana's "tart" before being discarded (248). She performs tableaux vivants or poses plastiques (2801), a type of Victorian modelling aimed at replicating famous artworks in real life (see Faulk, 142-187) as a Roman statue at Diana's party (Velvet, 308-9). The reaction of Diana and her upper class friends to Nan's: "appropriation of cultural capital" (Faulk, 147) exposes the insurmountable class barrier as they still treat her like a prostitute (see Sala in Faulk 150-4) (Endnote 1).

Nan's final, redemptive transformation is becoming Florence's lover, domestic 
help, and political helpmeet (Velvet, 348- 472), a conventional Victorian woman, with a twist. Florence, as a social worker, is not glamorous and does not fit the stereotype of fairytale princess, however, she is Nan's lasting love, a conclusion which references not fairytale but social realism, and it is to the influence of its most famous proponent, Charles Dickens, on Waters' novels that this thesis now turns.

The writing of the most celebrated Victorian novelist Charles Dickens influences Waters' narration, characterisation, imagery and use of social realism. Dickens is intensely and emphatically descriptive. Dickens often uses first person narration. Nan is consciously aware that she is the narrator: "That, however, is to get ahead of my story." (6). Kitty was born in Rochester (39), where Dickens lived and is an orphan, like Oliver Twist (1839) Esther in Bleak House (1853) and Nicholas Nickleby (1839). Dickens combines dark social realism and arguments for social change. Waters is not doing this but she perhaps has a political agenda of giving gay history prominence, making it less of a secret history.

Unpleasant characteristics are rendered in a Dickensian style. Walter Bliss has a watch-chain "as thick as the tail of a rat" (Velvet, 43). Nan feels: "stifled as a rat in a box." (61). London is depicted with Dickensian dirty realism, emphasising the squalor: "this street looked so very grey and mean." The landlady, Mrs Dendy, has an alarming cough and: "fingers quite yellow with tobacco stains" (68).

Pleasant experiences are rendered in Velvet as Dickensian comic whimsy: "I sat on the sofa with Bransby, and wrote a postcard to my family. 'I am in the queerest-looking parlour you ever saw,' I wrote, 'and everyone is extraordinarily kind. There is a dog here with a stage-name! My landlady says to thank you for the oysters..."' (Velvet, 76)

Dickensian realism can be seen in Waters' depictions of the music hall as a working environment. The relationship between Nan, Kitty and Walter realistically reflects gendered economic relationships in the Victorian theatre: Nan narrates that: "He negotiated our contracts, our publicity, and held our 
money for us; he paid Kitty and she, as before, gave me whatever little cash I needed, when I asked her for it." (Velvet, 135) (Endnote 2).

Dickensian realism about working class hardship is apparent, as Nan visits Whitstable:

The house, I thought, was shabbier than ever. ...the sign Astley's Oysters, the Best in Kent - hung on one hinge, and was cracked where the rainwater had soaked it. The stairs we climbed were dark and narrow, the room into which I finally emerged smaller and more cramped...Worst of all the street, the stairs, the room, the people in it, all reeked of fish! (154)

Nan reflects that, unlike in Whistable, winter was popular with those who worked in the theatre industry: "I remember my brother Davy sitting at our parlour fire on January evenings, and weeping... with pain, as the life returned to his split and frozen hands, his chilblained feet. ... frosts, and chill winds, fill theatres. For many Londoners a ticket to the music hall is cheaper than a scuttle of coal, or, if not cheaper, then more fun; why stay in your own miserable parlour" (91).

On discovering Kitty and Walter's affair, Nan runs away to a Dickensian underclass London, arriving: "at Smithfield, at the Dead Meat Market” (181). Her new room at Mrs Best's is "cramped and mean and perfectly colourless...bleached or grimed to some variety of grey." (183) Nan is "Miss Astley" again (184). Mrs Best slaps Mary, the little skivvy (186). As a prostitute, Nan is now part of hidden London (200-1).

Dickens' interest in politics began in his concern for the preceding social hardships. Political activism is featured in Tipping the Velvet. Nan first sees her rescuer-to-be Florence undertaking social work for poor people (219-221) and she introduces Nan to politics: "the Class Question, The Irish Question... The Woman Question" (226). The final chapters (Ch 15-Ch 19, 332- 472) include the presence of lesbians in public life, such as political movements, as well as in private sexual contexts of the late Victorian era. Nan participates in rallies for 
Union and Suffrage meetings (443-7). Her life is finally realistic, not theatrical fantasy. But this does not exhaust Waters' use of Victorian literary styles, as the following illustrates.

In Tipping the Velvet, Waters incorporates the literary characteristics of melodrama and morality tale, with reference to the gothic. Melodrama is a key aspect of theatrical pantomime. Nan describes then rejects the classic Victorian Melodrama- "my mother wept, my father struck me"- as a response to her leaving plans (59). Mr Astley is not the conventional Victorian patriarch maintaining that "children... weren't meant to please their parents" (59). Melodrama's obvious hints about plot are present in Tipping the Velvet. Of the first appearance of manager and love rival Walter Bliss Nan narrates: "I should like to say I felt a thrill of foreboding, but I did not. I only felt piqued, that our time alone together ... should be made shorter" (42). Nan's belief about her compatibility with Kitty is another dramatic hint about the end of their relationship. At this point in the novel both feel they have been given their "heart's desire" (72). However, Kitty's desire is for her stage career to flourish, while Nan's is to be with Kitty. "I know that Kitty and I felt just the same - only ...about different things. I should have remembered this, later" (72). A highly melodramatic, grotesque scene unfolds when Nan discovers Kitty and Walter together on her return. Walter's "face gave a kind of twitch, horrible to behold" (168). Nan's passage from innocence to experience is foretold: "Even then, I think, I didn't understand" (168) Kitty falls from grace: "drenched with tears and slobber" (169). Her spell - like hold over Nan is broken (172).

While melodrama is defined by theatrically heightened dramatic conflict which will nonetheless lead to a positive ending, morality tales depend on illustrations of immorality and their negative consequences. However, morality tales had as an adversary social and economic temptations, such as the glamour and remuneration associated in the popular imagination with a stage career. The Victorian actress commonly faced claims of immorality (Davis, frontispiece). Morality in melodrama is black and white. As a respectable working class girl, Nan is metaphorically "blemishless" (7). This is contrasted with the impurity of the actress. Nan compares Kitty's singing to "a fallen angel" (25). Nan charts 
her moral descent as she "ran to the station like a hoyden" (44). Nan's moral descent is mirrored by her departure from the Victorian domestic ideal. Nan neglects writing to her family (85). Nan's Mother reproaches her: they want regular contact from her, not expensive gifts (166). Nan's sister Alice writes a moral warning: "But look to yourself and the path that you are treading, and ask yourself if it is really Right" (134). She correctly asserts that: "You think you are happy, but you are only misled..." (134). Kitty stumbles onstage at Deacon's Music Hall, a reaction to being called a "tom" or lesbian (141). They depart Mrs Dendy's, their "honeymoon house" because sleeping together when they had money threatens Kitty's respectability (144-5).

Having initially benefited from her immoral behaviour, Nan now reaps the negative consequences. On fleeing Walter and Kitty and becoming homeless, men grope Nan as she walks alone in the city (191). She becomes a prostitute (197-200). Nan finds a new home with Mrs Milne and her "simple" daughter, Gracie (214). This is an opportunity for redemption, as is her initial meeting with social worker Florence, with whom she arranges a date (227) but she breaks both arrangements when she is seduced by the vampiric prowler Diana (233), an addict of "sensation" (249) and becomes her kept woman. She is thrown from the house when found in flagrante with a housemaid Zena (322-7), who then steals their money (336). Kitty continues her descent, becoming Bliss's 'puppet' in a sinister 'uncle/nephew' act. Waters appears to be influenced by secondary sources as Kitty and Walter are theatrically exposing "hallowed domestic scenes" (see Powell, xiv) and Kitty appears to be unconsciously mimicking pornographic conventions (see Davis, xiii, xv, xvi). At the novel's end, Nan lives as a housekeeper for Florence and her brother Ralph and minds infant Cyril. The love of social worker Florence and Nan's new domestic role redeems her. She aims to write again to her family after a long silence (Velvet, 468), spurning the reappeared Kitty's overtures at Hyde Park for the faithful Florence. (467). The melodrama is morally and satisfyingly resolved.

In a gothic style, this melodrama and morality tale contains horrific images and emotions. The London night is sinister: "the great dark jagged bulk of the 
Houses of Parliament looming over the river... its water grey and sluggish and thick" (101). Nan asks Kitty if she would cross the ice. Kitty undermines Nan's fairytale: "we would sink and drown; or else be stranded and die of the cold!" (102). Kitty's kiss sadistically flays Nan's lips (103). Nan thinks: "she loves me, she loves me - like a fool with a daisy - stalk, endlessly exclaiming over the same last browning petal" (106). "Walter's Plan" to put Nan onstage "made my stomach lurch in panic" (114). Nan feels herself: "melting exactly as if my chest were the hot, soft wall of a candle, falling in upon a burning wick. I was eighteen and knew nothing. I thought, at that moment, that I would die of love for her" (117). Violence or deathly threats are also gothic elements. Nan and Kitty's first kiss is swiftly followed by tragic news- comedian Gully Sutherland, the reason Nan first went to the Canterbury Palace, has shot himself through the heart (99). This event foreshadows Nan's later threat of violence towards Walter and Kitty: "'If you have hurt her' - he said. I laughed outright at that. 'Hurt her? Hurt her? I should like to kill her! Had I only a pistol on me now I would shoot her through the heart - and myself as well! And leave you to marry a corpse!"” (169).

Insanity and its associated degradation is another feature of the gothic. Walter declares that Nan has "gone mad" (173) in response to discovering his affair with Kitty. This reflects a literary convention of the 1880 s and 1890scautionary tales against women's participation in the theatre (See Faulk 113). Nan runs away, into London's labyrinthine streets, a "wood-louse or a rat" looking for a "small, mean room" to 'burrow or hibernate' in (181) Nan's appearance is Gothic: "wasted and grey, ... my eyes were swollen and purpled with shadows. My hair ...was long and filthy; my lips were bitten almost to the blood; my frock was stained, and rancid at the armpits. Mrs Best fears Nan is going to cut her wrists in the bath (188-9). Her heart has symbolically hardened and deadened (189-190). Such are the wages of Nan's movement away from a conventional career and sexuality.

It is the increased acceptability of alternative sexualities that has led to their inclusion in contemporary literature. Waters' writing is part of greater research trends into (especially queer) sexuality and Victorian history, particularly theatre 
and social movements. Theatre research has gained popularity as a window into the wider culture such as gender and the market economy (xiii). There is a similarity between Waters' interests and processes and Neil Bartlett's in researching gay London history for Who Was That Man? (1988) (Endnote 3).

Waters' interest in queer history is principally displayed through the characters of Nan and her love interests, Kitty, Diana and Florence. Waters' use of terminology in communicating this history is deliberate. Incidentally, Nan and Kitty's stage names, "Nan King" and "Kitty Butler" are also disguises like the metaphors and double entendres Waters uses to refer to Victorian gay and lesbian society. This is relevant because these terms were not in contemporary use, and would not have been a respectable topic of direct social discussion. The terms "gayest" and "queer" (Velvet, 7,17, 76, 183), while with different meanings in Victorian times, in a camp way highlight the hidden sexual subculture. While her father appears in denial, saying her trips to the Palace to see Kitty are a cover for carrying on with a boy from the orchestra (19), Nan is described by her brother Davy as being "mashed out on a masher" which implies, albeit jokingly, that she has a crush on the cross-dressing Kitty. While Waters' use of these terms is playful as well as historically accurate their vagueness or slang nature does not ultimately provide social protection against their being used with derogatory force in the novel. Kitty rejects another female duo as "toms", when Nan claims similarity and wants to make friends with them. (Velvet, 131) Later they are verbally attacked as such in an East End theatre (140).

Indirect, suggestive terminology is used not only to describe sexual orientation but sexual practices. Lesbian sex is metaphorically suggested by the food served in Astley's oyster parlour: "The little fish sat in the palm in its bath of oysterjuice, naked and slippery" (48). Nan's father describes the oyster as a "real queer fish", a "morphodite" [hermaphrodite], while theatre manager Tony compares Kitty to an oyster (49). When Mrs Dendy shows Nan and Kitty to their bedroom she says: "You won't mind doubling up, of course...You'll be quite on top of each other in here - though not so tight as my boys downstairs, who only have the one room" (70). One, Sam Willis says: "This is Percy, my 
brother, who plays the Bones. He's also extraordinary. As he spoke Percy gave a wink" (74). In fact, Percy plays the spoons. Both descriptions of instruments are suggestive of a sexual relationship - "bones" is phallic and "spoons" is a sexual position. This is a relationship for which the description of 'brother' is a possible camouflage.

There is a similarity between the hidden language of homosexuality which Waters employs and the hidden position of homosexuality within the theatre world. Nan and Kitty's love is invisible to Walter who exploits it as a double act (Velvet, 110). Nan reflects that: "making love to Kitty and posing at her side in a shaft of limelight, ...these things were not so very different. A double act is always twice the act the audience thinks it: ... there was a private language..." (127-8). This is similar to Dorian's remark in Wilde's Dorian Gray: "I love acting. It is so much more real than life." (65). Both novels involve idealised homoerotic relationships that lead to ruin and a path from innocence to experience.

Waters uses the history of popular culture as a source for Velvet. The idea of trends in popular culture is incorporated. As male impersonators become common, Kitty's popularity stalls (87). Waters appears influenced by secondary sources. Davis rejects "the myth of the rise of the Victorian actor" (xiii) to middle class prosperity. This myth of social mobility proposed that someone from the working classes could rise to the middle classes and even beyond through a stage career. In reality, because of competition for parts and insecure work, an actor or actress was often likely to suffer greater economic hardship than if they had remained in a relatively secure working class profession. Nan's career and lesbian relationship with Kitty are explicitly linked: "And so the day that I became Kitty's sweetheart was also the day that I joined her act, and began my career...on the music - hall stage." Nan interacts with popular culture, even while preparing oysters. We read of "her lips continually moving to the words of some street-singer's or music-hall song." (4). We learn of her trips to the music hall in nearby Canterbury Palace of Varieties (5-6). Its manager, Tony Reeves facilitates Nan seeing Kitty. (15) Later, Nan and Kitty sing popular songs in their bedroom (109-110). Interest in the occult is another aspect of 
popular culture and Nan's attempt to use "mentalist" powers to make Kitty notice her (18). At Mrs Dendy's, they live with a mentalist, Professor Emery (73).

Nan and Kitty's act, as young men enjoying the liberty of London (a phenomenon noted by Wilson 23-35, 57 in Faulk, 13) places their relationship in an authentic popular cultural context. Waters appears to use her secondary sources to 'create' lesbian history and place lesbians at the beginning of the evolution of camp (a tradition more usually associated with gay men) and one which links historic lesbian culture to contemporary camp (Endnote 4). This is a political act by Waters which 'de-invisiblises' Victorian lesbian society, mirroring contemporary lesbian political belief in a lesbian presence throughout history, 'evidence' which secures contemporary lesbian identity. While evidence of Victorian Sapphic identity does exist, Waters draws on illegal and therefore more visible gay male history to supplement this, creating a history that is in some senses imaginary.

There is an overlap between London's theatre land and its sex trade and sexual underworld. Theatre land is the ideal world to pick up customers (ibid, 207). Having fled into the London streets, Nan wears boys' clothes to protect herself and establish freedom and independence. (191-2). She then becomes an apparently male prostitute or "renter" (202), a world of performance, which is the dark mirror image of the theatre world (203). She makes friends with Sweet Alice, a mary-anne or transvestite male prostitute (ibid, 203-205). Nan's involvement with an aristocratic street crawler Diana shows Waters is influenced by the scandal of playwright Oscar Wilde's pursuit of rent boys (see Melville, 250).

Waters' treatment of pornography and physicality references secondary sources that reveal aspects of Victorian attitudes towards sexuality and homosexuality. During his trial, Oscar Wilde redefined his relationships with other men as intellectual relationships, as physical relationships were illegal (see Dowling, 23). At Diana's mansion, Nan is entertainment for the "Cavendish Sapphists" (Velvet, 279) involved in romps reminiscent of Victorian pornographic literature with her Mistress (241-244): "For on the top of the jumble, on a square of 
velvet, lay the queerest, lewdest thing I ever saw... It was, in short, a dildo" (241). She is cast from the mansion when she is found using it on the maid. The physical acts of lesbianism that take place in the aristocratic Diana's home are rendered grotesque, which apparently reflects this Hellenist intellectual homosexual tradition referred to by Dowling (2-3). This was presented by Victorian advocates as a tradition of intellectual, not physical intercourse between male students and/ or their lecturers, based on the 'pure' intellectual interactions between ancient Greek philosophers and their young male students. Of course, ancient Greek society also condoned sexual relationships between older and younger men within the context of intellectual relationships, and critics suspected, not without reason, that the Victorian Hellenic tradition was an alibi for homosexual activity.

However, relationships that Waters wants us to view more positively, (such as the between Kitty and Nan) also fit into the (physically focused) Victorian pornographic tradition: "At last she was naked, all except for the pearl and chain about her neck" (Velvet, 104). With reference to James Atherton's The Books at the Wake (1974) Presley (1996) reveals that The Pearl, A Journal of Facetiae and Voluptuous Reading (1879-80) was one of many pornographic magazines that flourished in Victorian England" (67-80) and Waters' prose is reminiscent of such works. Nan's final romance is with social worker Florence, with whom there are also explicit sex scenes (Velvet, 428).

\section{Conclusion}

What pulls all of Waters' sources together is that they are either authentic aspects of Victorian Literature or reflect recent trends in Victorian historical and literary scholarship. What distinguishes Velvet from Waters' other novels is that it is more playful in subject matter and paradoxically more implicitly political in its specific references to political movements. 


\section{Endnotes}

1. See the discussion in George Augustus Sala, Gaslight and Daylight and Saturday Review.

2. See the discussion in Tracey Davis, "Actresses as Working Women: Their Social Identity in Victorian Culture".

3. See the discussion in Neil Bartlett, Who Was That Man? A Present for Mr Oscar Wilde. Bartlett recounts his discomforting process of researching ignored and stigmatised gay history within libraries. Also see Waters, quoted in National Archives: "Lesbian and Gay History Getting out There" in which she praises the new researcher-friendly highlighting of gay and lesbian content.

4. See Arthur Symons in "A Spanish Music-Hall," in Cities and Sea-Coasts and Islands and Susan Sontag, "Notes on Camp," in Against Interpretation. 


\section{Affinity: "Queer? I should say it is criminal!"}

Waters' second novel, Affinity (1999), is infinitely darker in subject matter and conclusion than its predecessor, Tipping the Velvet (1998), particularly because it ends with the death of the heroine. Prison Lady-Visitor Margaret Prior is recovering from a suicide attempt, still grieving the death of her father and the marriage of her lover Helen to her brother Stephen, and lives with her domineering and disapprovingly conventional mother. She falls in love with a prisoner, Selina Dawes and becomes ensnared in the latter's plot to escape Millbank prison. Margaret becomes convinced of Selina's spiritual powers and Selina's love for her, but this is revealed as a hoax. When Selina steals her money, escapes and abandons her, leaving Margaret to take the blame for her escape, Margaret heads towards a watery suicide in the Thames.

Waters' use of fairy-tale in Affinity is akin to the Brothers Grimm's use of gothic fairy-stories as morality tales, but she also uses the Victorian interest in new religious movements such as spiritualism. Margaret is offered spiritual transformation through the putative powers of Selina Dawes and unsuccessfully risks her life on her belief on the word of this criminal. When Lady-Visitor Margaret Prior first glimpses Millbank she is like a princess in a fairy story glimpsing an evil black castle. She fusses with skirts which have "caught upon some piece of jutting iron or brick...lifting from my eyes from my sweeping hem that I first see the pentagons of Millbank...I look at them, and feel my heart beat hard, and I am afraid" (Affinity, 8). The architectural pattern of Millbank: "has a curious kind of charm to it" (8) and is like "petals on a geometric flower" (8) and a children's board game, enhancing its sinister bewitching, magical feel. Margaret thinks it looks like it was designed by a madman: "to drive its inmates mad" (8). The geometry of Millbank is mazelike and makes Margaret "giddy" (19) like a spell. In fairy-tale style it features spiral staircases and towers (1920). In a reference to Christina Rossetti's 1862 poem Goblin Market, Margaret whimsically imagines the male inmates are "goblin men, with snouts and tails and whiskers...” (35).

Nature and environment in Affinity are sinister with agency. When Margaret walks in to Millbank she feels the walls advance "like the clashing rocks of the 
Bosphorous" (8) and there are "fogs that seem to rise from the pavements as if brewed in the sewers in diabolical engines." (125).

Inmate Selina (imprisoned for fraud and assault) reminds Margaret of the portrait of a saint or angel by Italian artist Crivelli, and she observes that Selina has fresh violets in her cell on which she appears to have a magic effect: "As I watched, she put the flower to her lips, and breathed upon it, and the purple of the petals gave a quiver and seemed to glow". She seems so magic that everyone else around her seems unreal, or painted. The warder informs Margaret that no flowers grow in Millbank soil. (26-7)

In Affinity, Waters offers us the possibilities of magic realism as a plot mechanism but ultimately exposes spiritualist effects as tawdry materialism. Margaret and the reader are offered signs purporting to be spiritual activity which cannot always be rationally explained, or about which there is conflicting evidence.

Margaret is offered the prospect of personal transformation in personality and circumstances by embracing spiritualism. The fairy tale offered is that Selina, with Margaret's help, will escape Millbank by spiritualist means, and they then will escape the darkness of London. Mirroring is a common aspect of fairytale and another type of transformation, in that Margaret and Selina are in some ways alike. The women are prisoners in different ways - Margaret a prisoner of the home and her mother, of the middle class spinster's fate, of grief for her dead father; Selina of poverty, of Mrs Brink, Vigers and of Millbank. Ultimately they swap roles, as Margaret is threatened with imprisonment, while Selina has freedom. In addition, the villains of those who threaten the happiness of both women are predominantly female. Margaret dreams of sunny Italy, and Selina has the same dream, although it involves robbing the former of her life in every aspect.

Drugs such as chloral and laudanum are also (forcibly) proffered as transformers: of illness into health, but ultimately of realistic perception into delusion. As Jane Wood argues in Passion and Pathology in Victorian Fiction, 
women were portrayed as nature's invalids (Ch 1, 8-43). The transformation of otherwise healthy women into invalids through the female, repressive matriarchal and patriarchal control is a significant feature of Victorian society and is reflected in the novel.

The possibilities of moral transformation through Christianity (God the Father is symbolised by Margaret's loving but dead father) are officially proselytised by Millbank prison. Millbank's prison governor $\mathrm{Mr}$ Shillitoe verbalises the apparently 'compassionate Christian' approach to "these poor women" inmates (Affinity,11). The reference to "all the dark and crooked paths through which they have made their way to Millbank" (11) reminds of how they have strayed from the narrow path of Christianity. He describes their imprisonment as "close care" (11) involving regular habits, prayers, modesty. But he defends keeping them in solitary confinement where they are inclined to brood and declares a Lady Visitor can turn these savage childlike women into penitents, moulding themselves on their betters. (11-12). In Victorian society it was often argued that morality was dependent on class. This belief in the ideal of middle class women sets a trap for Margaret, as this philosophy assumes there is no risk to her, because she is morally impregnable: "For a moment I wished only that they might see the weakness in me, and send me home..." (12)

If the moral transformation offered by Christianity is rejected, then the judgemental conclusion of the Victorian morality tale comes into play. Morality tales end with the triumph of good over evil, or, evil over good, if the victim has not taken enough caution. Margaret ignores conventional wisdom and morality. She declines to read inmates the Bible in favour of listening to their stories (22). Mrs Prior, with her fetish for social reputation, is repressive and controlling of her daughter Margaret. This is a red herring because it leads Margaret and the reader to think their judgements of prisoners and of risk to Margaret must be wrong. Mrs Jelf, the only kind matron, whom Miss Craven describes as "a bit soft” (37) falls victim to Selina (329-338). Margaret Prior ('Aurora') ultimately falls into Selina Dawes' spiritualist trap. Selina uses her apparent connection with the spirit world as a form of moral ballast, as to her good character and her love for Margaret, convincing Margaret to help her escape. Within context of 
the heroine's tragic impending suicide on discovery of Dawes' deception - that the spiritual proof was just trickery and the love is fake. Both Christianity and alternate spiritual movements are rejected in Affinity in favour of 'the survival of the fittest', embodied by the criminal Selina, by any means necessary, regardless of morality. This literary mode could be described as Gothic Darwinism (Endnote 1).

As in Tipping the Velvet, Affinity uses the conventions of the Victorian novel, especially those of Charles Dickens and Wilkie Collins. Dickensian narration, social realism, characterisation and imagery are all present in Waters' works. Waters mimics Dickens' style of naming characters in a manner which suggests something about them, their role or their personality. "Selina Dawes" suggests a door to the spiritual realm, Mrs Brink is on the brink of the same, "Peter Quick" suggests a short temper, and perhaps, although not Dickensian, the vengeful ghost Peter Quint from Henry James The Turn of the Screw (1898). "Ruth Vigers" suggests a masculine vigorousness which links her with Peter Quick; "Margaret Prior" a nun like existence, cloistered at home or Millbank, and thwarted sexuality. "Miss Haxby" sounds close to a hex, an evil spell, "Miss Ridley" suggests the riddle of guilt within the narrative, and of Millbank's geometry, "Miss Pretty" is ironic and Mr Shillitoe references a lowly body part.

Dickensian novels are replete with highly memorable villainous characters which are central to the narrative. They are often portrayed in a three dimensional fashion so that one has some sympathy for them, while ultimately condemning them. Selina Dawes is arguably one of these, as we are privy to her perspective and feelings through her diary. Villainous holders of conventional morality such as matron Miss Ridley are sadistic towards prisoners, but in some aspects have superior critical judgement: "Do you think us harsh, Miss Prior?... Take care she gave the words a dreadful emphasis - Take care, in your dealings with Millbank's women!" (16).

Many of Dickens novels are bildungsroman, coming of age novels, such as Nicholas Nickleby (1839), and Great Expectations (1861). However, in Affinity, Margaret's coming of age, her trip to Italy with her father, is aborted by his 
death, and her adulthood is malformed by her mother and enforced medication, Helen's rejection of her as a lover, and the repression of her sexuality which is diverted into the prison world of Millbank and Selina Dawes. Dicken's bildungsroman may have bitter-sweet conclusions of wisdom gained at the expense of youthful naivety and joy, but do not end with the death of the hero/ine narrator for whom wisdom does not arrive in time to save them. An important feature of Dickens' bildungsroman is the attendance of a benevolent older friend who balances out the evil influences of any villains. In Affinity, the closest Margaret Prior has is former lover, Helen, with whom she has a strained relationship with, and her husband, Margaret's brother Stephen, who is wise, but ultimately not cautious of her sanity or protective enough. Unlike Pip in Great Expectations, or Nicholas in Nicholas Nickleby, she is not a young man helped to find his way in the world, but a spinster whose life is expected to be an adjunct to her family. If Bleak House is a bildungsroman of Esther, her quest is not a career, but finding her mother. Margaret is not seen to want anything adventurous, let alone reckless.

Many Dickens novels portray underclass London with all its attendant sinister imagery. In Millbank, the underclass are captured and on display to captors and visitors - not unlike the East End, which was a 'foreign country' to upper class tourists during the Victorian era. Dickens described the sinister seediness of the River Thames (the environment of the Mud-larks in Our Mutual Friend, who recover the drowned, suicides, the murdered). Waters describes the Thames marshland in Affinity being a place in which nothing grows (28) and "as black as molasses" (30). As a river, the Thames runs to the ocean to which a matron compares Dawes: "Deep, I call her" (Affinity, 42), and suicide by drowning is the fate which awaits Margaret. At the novel's end Margaret compares herself to the river. This foreshadows the fate of suicide by drowning which awaits Margaret in Affinity:

For oh, I am so terribly weary at last! I think, in all of London, there is no-one and nothing so weary as I - unless perhaps the river, which flows on beneath the frigid sky, through its accustomed courses, to the sea. How deep, how black, how thick the water seems to-night! How 
soft its surface seems to lie. How chill its depths must be (350-1).

Martha in David Copperfield (1850) has been a prostitute and is saved from suicide on the banks of the Thames. She makes a similar speech after she is rescued from a suicide attempt:

I know it's like me!" she exclaimed. "I know that I belong to it. I know that it's the natural company of such as I am! It comes from country places, where there was once no harm in it - and it creeps through the dismal streets, defiled and miserable - and it goes away, like my life, to a great sea, that is always troubled - and I feel that I must go with it! (662)

Dicken's social realism may be seen in the portrayal of certain aspects of domesticity, the 'at home' lifestyles of different classes, and changes in domestic fortune for better or worse, and Selina's social advancement and fall may be viewed in this light. Both Selina and Vigers are or have been servants, Selina as a domestic spiritualist. Dickens' sinister characters, include the expressedly humble but actually resentful social climber Uriah Heep (David Copperfield). Such characters in Waters, as with Dickens, reflect the Victorian middle class fear of being usurped by social-climbing, scheming servants, which may have its origins in the fact that many of the Victorian middle class were newly so and felt the need to protect their position while hiding their humble origins.

Social arguments are an important aspect of many Victorian novels, including those of Dickens. One such argument is about the dehumanisation of industrial society with its attendant poverty. Dickens would describe humans becoming things, being made by society. In his journalistic piece “On Duty with Inspector Field" (Household Words, 1851) he describes some tramps as: "the infected, vermin - haunted heaps of rags" (152) but within a humanistic narrative, exposing the rigid meanness of the class system. Waters imitates this: female convicts seen from a high window are: 
dolls upon a clock, or beads on trailing threads. ...three great elliptical loops...the loops were seamless, and the women all dressed quite alike...It was only from their poses that I caught the humanity of them: ...there were some, I saw, with drooping heads, some that limped; some with bodies stiff and hugged against the sudden chill, a few poor souls with faces lifted to the sky - and one, I think, who even raised her eyes to the window that we stood at, and gazed blankly at us...ninety women to each great wheeling line...Mrs Haxby, I thought, gazed at the plodding women with a kind of satisfaction. 'See how they know their places,' she said. (13-14)

Waters reflects Dickens interest in and use of the novel to argue the case for social issues - one inmate is there for failed suicide (23), another for procuring an abortion (77), another, a seduced servant who murders her baby (40-1). There are also children imprisoned. (42).

Waters is influenced by Dickens' comic grotesques. When Stephen says: “They are...born with the chains already swinging from their hips. Their mothers gave them iron keys to suck, to make their teeth come" (36), Margaret responds with this caricature:

Suppose she wasn't born to it, but rather sweats and labours to perfect the role. Suppose she has a secret album, cuttings from the Newgate Calendar. ... She has put a label on it, Notorious Prison Martinets, and she takes it out and sighs over it, in the small dark hours of the Millbank night - like a clergyman's daughter, with a fashion paper. (36-37)

Then fear of Ridley makes Margaret "shudder" undermining that picture, taking the text back into the realm of the sensation novel. (35-37)

Waters also uses Dickens' suspenseful, dramatic handling of murder scenes. The murder of Nancy by Bill Sykes in Dickens' Oliver Twist is reflected in the assault of Madeleine Silvester by Peter Quick (Affinity, 1-2). Describing 
Nancy's death, Dickens writes:

She staggered and fell, nearly blinded with the blood that rained down...The murderer, staggering backward to the wall and shutting out the sight with his hand, seized a heavy club and struck her down... The sun - the bright sun that brings back, not light alone, but new life, and hope, and freshness to man - burst upon the crowded city in clear and radiant glory... It lighted up the room where the murdered woman lay. It did. He tried to shut it out, but it would stream in. ...And there was the body - mere flesh and blood, no more - but such flesh, and so much blood! (Oliver Twist, 1992, 362- 363)

The bloodiness, deathly stillness of the victim, guilt stricken alarm, and reaction to exposure by light can all be found in this following passage by Waters:

Then Peter leaned \& hit her on the cheek, \& after that she lay very quiet and still. Then I thought we really might have killed her. ... Mrs Brink was there...she was holding a lamp. I said 'Close the door, here is Peter look \& the light is hurting him!' But she said only 'What has happened? What have you done? She looked at Madeleine lying stiff upon the parlour floor with all her red hair about her, \& then at me in my torn petticoat, $\&$ then at the blood upon my hands, which was not black now but scarlet. Then she looked at Peter. He had his hands before his face \& was crying 'Take the light away!' (Affinity, 2)

Like Wilkie Collins' The Woman in White, Affinity is a sensational narrative of foul play, as devoured by Victorian readers (Sweet, xiv). Neither novel has an omniscient authorial narrator. Their narratives are told by the characters who present often different and contradictory perspectives. Affinity has two narrators, so the reader has to choose between two different perspectives, that of the heroine Margaret and that of the villain Selina. We develop sympathy for both. Multiple narrative perspectives were a feature of many Victorian novels. Sweet writes of The Woman in White: 
The subjective structure of the novel suggests that its testimonies might contain a whole world of equivocation, doctoring and deliberate ambiguity. Lies are told; texts invade other texts. ...After reading The Woman in White, one can never quite believe in any novel as a seamless artefact untroubled by internal contradiction. Indeed, one can never quite trust a narrator again. (xxxi)

Dickens' Bleak House alternates the authorial narrative with Esther's narrative, which may owe something to Collins.

As with The Woman in White, Affinity is a sensation novel, with its roots in domestic settings and trials:

For the protagonists of The Woman in White, home is a place where you fall ill and risk being...driven insane. Collins and his fellow sensationists re-mapped the 'knowable communities' within which writers such as George Eliot, Elizabeth Gaskell and Margaret Oliphant plotted their fictions as territories that were unknowable, or at least dangerous to know. Their readers found this both alarming and exhilarating. (Introduction, The Woman in White xiv)

Women were generally confined to domestic spaces, where they were often framed within Victorian society, or depicted in the Victorian novel, as ill. Domestic illness is another feature that Affinity shares strongly with The Woman in White. In Passion and Pathology in Victorian Fiction, Jane Wood discusses the Victorian medicalisation of womanhood, how being female was seen as quintessentially unhealthy and in need of intervention and treatment $(\mathrm{Ch} 1,8$ 43). David Copperfield's wife Dora is a Dickensian example of an hysterical female character. Dora cannot cope with stress at all and dies young, never having regained her health after a miscarriage.

Margaret's illness derives from her domestic circumstances. In keeping with the conventions of the sensation novel, Margaret is drugged by her mother, tricked by Selina, and terrified by prison. In one instance, she narrates her heart literally 
racing: "My heart beat even harder then, ... When Mr Shillitoe came to me at last, I took his hand. I said, I am glad to see you! I had begun to worry that the men might take me for a convict just arrived, and lead me to a cell, and leave me there!” (9). As Sweet argues:

Without the comfortable distancing device of an authorial voice... readers were excitingly proximate to the sensations suffered by the protagonists. During the course of The Woman in White, its narrators are attacked, drugged, tricked and terrified. Their subjective accounts of these harrowing experiences position the reader in the same disadvantaged position (xvi).

Part of the sensation for the reader is the proximity to the criminal mind: "instead of events being mediated through the ironic voice of an omniscient narrator, Collins allowed his characters to speak for themselves like witnesses at a criminal trial" (Sweet, xvi) (Endnote 2). Selina and Margaret both speak like witnesses at a criminal trial; indeed, Selina narrates her court trial and Margaret narrates her responses to information on Selina's trial. Selina is also figuratively 'on trial' for her fraud of Margaret, and Margaret is 'on trial' for disobeying convention and assisting a criminal to escape.

The first person narrative of Affinity is in diary form, alternating between the accounts of Selina and Margaret and opens on 3 August 1873, with the "frightened" Selina's account of a séance which went wrong, due to malevolent spirit Peter Quick, resulting in her imprisonment (1-2), inducing sympathy and apprehension in the reader who is not sure if she is she innocent, or if guilty, still a sympathetic character. Waters is misleading the reader, mirroring Selina's tricking of Margaret later in the novel.

The structural alternation between the diary and interior monologue narratives of Margaret and Selina creates suspense. This is not dissimilar to the effects created by Collins:

Narrators like Marian Halcombe and Walter Hartright collapse into 
silence, leaving the reader with a page of blank text, a line of asterisks, a question unanswered until the next volume or number. Unpoliced by any narrator, they are also free to lie to us. Count Fosco's testimony contains obvious untruths. Might Walter's account of himself also contain deliberate errors, elisions or self-justifying fictions? How do we know that their narratives are not misleadingly partial...?" (Sweet xvi-xvii)

The first person narratives by Selina effectively encourage the reader to identify with her, give her the benefit of the doubt, suspend judgement and feel sympathy. Selina narrates the incident which led to her imprisonment, in which she says spirit Peter Quick assaults Selina's client Madeleine Silvester: "I was never so frightened as I am now...Peter, what have you done? Go back! You must go back!" (Affinity, 1-2). Selina's final diary shows the extent of her duplicity: “"Remember,' Ruth is saying, 'whose girl you are"'(352). However, the reader can no longer suspend their judgement and give Margaret's belief in Selina the benefit of the doubt, because of her obvious delusional state towards the end of the novel: "I shall take a dose of laudanum, and perhaps that will guide her to me" (316-318).

Waters includes lesbianism as a feature of Victorian society, particularly associating it with criminality, prisons and spiritualism:

The Doctor says this was a queerer business than he thought. Mrs Silvester said then, 'Queer? I should say it is criminal!' (3). The Doctor says this after Madeleine Silvester faints after a blow from Peter Quick, a spirit which Selina has summoned. Mrs Brink has died from the shock of seeing the resultant scene. Selina is then locked in her room, apparently by the Doctor and Mrs Silvester, while the police are summoned.

This sentence is a key to the novel's siting of lesbianism within Victorian society, as quasi- criminal, if not actually illegal. This description has a pantomime aspect, not unlike the usage of 'queer' in Tipping the Velvet. There is 
humour in that a contemporary readership is aware of its double meaning - both ambiguously peculiar, but sexually unorthodox.

In Affinity, as in Victorian society, lesbianism is tacitly a crime, reflecting its social status of abnormality. Affinity is a (fictional) secret history. Lesbianism, unlike homosexuality was not a crime on the statute books. However it was still an anathema, and regarded as a mental illness. It seems symbolic that Madeleine's doctor locks up Selina, so the police can take her away. It is implied that Margaret's nervous illness is caused not just by the death of her father but her terminated love affair with Helen, who is not brave enough to continue the relationship.

There is an implied sexual aspect to Selina Dawes' crime, that she sexually assaulted Madeleine Silvester. It later turns out that this was Ruth Vigers, her maid and lover as the spirit 'Peter Quick'. There are quasi-sexual overtones to Mrs Brink lying on Selina's chest, ostensibly to connect with the spirit of her mother (173-4). Selina's séances have a sensual aspect, involved her rubbing, shampooing, removing articles of clothing, laying on of hands, on women (145).

Millbank's matrons seek to thwart prison lesbianism. Manning warns Margaret: "You must watch that no-one tries to make a pal out of you, miss" (67). Margaret reflects on her discomfort "that I had almost played the medium, innocently" for the lesbian relationship of two prisoners (67). This foreshadows her role as unwitting medium for Selina and Vigers' relationship. Margaret's attraction to Selina is expressed by the former's interior monologue about the latter's appearance and similarity with her 'ex girlfriend' Helen (45) and physical touch $(49,87)$.

Affinity's women are locked up, controlled, tortured, drugged, mostly by other women. Margaret is relieved Millbank is unfamiliar with her history of mental illness. "I imagined them fastening my own past shut, with a strap and a buckle" (29). The initials of Selina and Margaret (or Madeleine) play on 'S\&M' or sadomasochism. Selina, wearing a velvet collar, would be tied with knots sealed with wax and untied by a lady or sitters afterwards (153-4). In the context of 
lesbianism, spirituality and prisons, this gives the novel a subtle pornographic quality. The texts in Waters first novel, Tipping the Velvet, and third novel, Fingersmith play with the idea of the pornographic and in Fingersmith, pornography is also a subject. However, Waters second novel, Affinity, contains no sex scenes; instead, scenes of restraint or imprisonment are erotically charged.

Affinity reflects some aspects of Victorian prison novels and biographies. Details of prison conditions in Affinity correspond with accuracy to those outlined by Philip Priestley in Victorian Prison Lives: English Prison Biography 1830-1914 (1985). These include an illustration of Millbank Prison's 'labyrinthian' pentagonal outline (Preistley 24, Affinity, 7-8) the removal of prisoners hair (Preistley 22), prison reading materials (33), bedding (32), spyholes (30), the rule of silence (33-39), convict dress (53), imprisonment of children (55), women in prisons (69-73), women visitors (104-105), Female warders (265), (male) warders and governors (252), discipline (193-232), diet (148-167) and sickness (168-192).

Attempted suicide was a crime in Victorian England. Margaret's thwarted lesbianism, and manipulation of it by Selina, is associated with her suicide attempts and impending suicide at the end of the novel. Barbara T. Gates critiques the Victorian fascination with female suicides (Ch VII, 125-150) and their belief that the only good "fallen woman" was a dead one and only then could she be properly romanticised and lamented (131-132). There was a strong Victorian association with female suicide and drowning. As in the case of John Everett Millais's painting Ophelia (1851-52), suicide by drowning was romanticised as particularly feminine and beautiful (Gates, 136-140). Affinity's heroine follows this by intending to drown. Margaret also made earlier attempts involving poison which also has overtones of femininity. In Wilkie Collins' The Law and the Lady (1875) Sara Macallen "poisoned herself with the arsenic initially and pathetically purchased to clear her complexion and make her more attractive to her husband" (Gates, 57). It appears to have been considered necessary for the female suicide to be particularly feminine in order to make up for her transgressions of femininity. 
In The Newgate Novel 1830-1847: Bulwer, Ainsworth, Dickens and Thackeray (1963) Keith Hollingworth outlines the key features of the genre: "Between 1830 and $1847 \ldots$ a series of novels having criminals as prominent characters aroused widespread attention. ..." (14). Hollingworth argues: "The novelists examined the criminal as one who, however perverted, must be recognized as belonging to the human family" (27). This accompanied reform in criminal law (24). Dickens' Oliver Twist and Great Expectations are both in some respects Newgate Novels, in which the portrayals of convicted felons Magwitch and Fagin (Hollingsworth 25) have sympathetic aspects or redeemable qualities: "The Newgate novel began as an instrument of protest against the severity of criminal law and against the structure of class privilege which that law represented" (222). The disadvantaged class position of Selina and its role in her offending is one feature that makes her character sympathetic. Capital punishment is a key topic of the Newgate Novel. However in Affinity it is not in any way a subject, let alone a focus.

\section{Conclusion}

Affinity is Waters' first novel which involves a critical discussion of the Victorian criminal justice and prison systems, which did not figure at all in Tipping the Velvet, despite Nan's illegal employment as a prostitute. It is a subject she returns to in third novel Fingersmith, and fourth novel Night Watch, where characters are also imprisoned. Both of these novels continue Affinity's powerful theme of sensation but with happier melodramatic conclusions.

\section{Endnotes}

1. This reflects the challenging of Christianity by Darwinism in the Nineteenth Century. In Annie's Box: Charles Darwin, his Daughter and Human Evolution by Randal Keynes argues that the death of Darwin's much loved young daughter Annie from illness assisted in convincing the scientist that there were evolutionary forces at work rather than the hand of God.

2. Sweet notes that:

John Sutherland has argued persuasively that it was the famous 
William Palmer poisoning case that gave Collins the idea of offering his story as a package of subjective testimonies (see "Wilkie Collins and the Origins of the Sensation Novel", Dickens Studies Annual 20 (1991), 244-58). Collins had, however, used a slightly less ambitious version of this technique before in Basil (1852), a novel that combines a chunk of unfinished memoir, a fragment of diary and a bundle of letters to effect the same sensational explosion of authorial omniscience. The Dublin University Magazine (February 1861) accused him of stealing the device from Dinah Mulock Craik's A Life for a Life (1859). (xxxii) 


\section{Fingersmith: "I thought it was her face she supposed she saw".}

In Fingersmith (2002), the two main female characters were swapped at birth. Sue Trinder, adopted daughter of baby farmer Mrs Sucksby, plots with confidence trickster Gentleman to become a maid to a wealthy heiress, Maud Lilly, to help him marry her, steal her money, send her to a mental asylum. As payment, Maud will take half of the inheritance. However, the trick rebounds on Sue, who finds herself passed off as Maud by Maud and Gentleman and confined to the asylum. After escaping from the asylum, she returns to Mrs Suckby's, where Maud accidentally kills Gentleman and Mrs Sucksby takes the murder charge and is hanged. Sue discovers that she is in fact the heiress, and Maud is really Mrs Sucksby's daughter. Mrs Sucksby and Sue's mother Marianne switched the girls at birth, so that Maud could be raised as a gentlewoman, and Sue would be safe from Marianne's father and brother.

Fingersmith possesses the most thoroughly complex of Waters' narratives, yet Waters also manages to incorporate a wealth of themes, characterisation and influences. This reflects Victorian novels which Henry James described as "loose baggy monsters" at a time when instalments were serialised in magazines and readers had to be engaged over long periods. Readership was high due to increased literacy and competition from other forms of media was more limited than today.

Storytelling is a theme of all of Waters' novels. In Fingersmith, characters are aware that they are telling stories, or being told stories, while at the same time oblivious to the true story of their identity. The theatre play of Oliver Twist, at which Sue is present and which Fingersmith opens with (3) is a story within a story, which seems indicative of this tendency. In an ironic reflection of the closely proximate presence of the Oliver Twist play in the narrative (3-7), Mrs Sucksby acts her distress at Maud's mother's fictional hanging as a murderess: "So Mrs Sucksby told it; and every time, though her voice would start off steady it would end up trembling, and her eyes would fill with tears" (11). Readers are commonly asked to suspend reality and embrace illusion. Waters hints at the 
creation of the illusion by making the reader aware of the story she is weaving. In Maud's asylum birth, blood drips like ink (179). Sue says: "You are waiting for me to start my story. Perhaps I was waiting, then. But my story had already started - I was only like you, and didn't know it" (14). On returning home to Mrs Sucksby after escaping the asylum, Sue confronts Mrs Sucksby, Gentleman and Maud in words that reflect Waters' conscious storytelling and the fiction that Sue has been told about her life:

"Do you suppose a girl is sitting here? That girl is lost! ... She has only bones, stripped white! She is as white as a page of paper! She is a book, from which the words have peeled and drifted - ...My life was not lived, I say in a whisper. You have told me, it was a fiction." (336337)

Gentleman responds nastily: "fictions must end. Hear now how yours is to" (336-337).

Fingersmith is primarily a historical novel, but not a straight historical novel because the characters' life scenarios, both real and imagined, use gothic and fairy-tale imagery that have a transformative effect on otherwise realistic characterisation.

In swapping places as infants, Maud and Sue are like fairy-tale changelings. And this is not the only fairy-tale plot that Waters employs. As in Cinderella, Sue wears Maud's silk dress while Maud dresses like a servant (168-171). As in Sleeping Beauty Sue's kiss transforms the apparently innocent Maud (88). Furniture in Maud's darkened parlour is like the baskets in which Ali Baba's thieves hid. This is the scene is which Maud convinces Sue of her terror and convinces her to stay with her in her bed (86-89). The implication is that Maud is a thief of Sue's sexual innocence, as well as being a metaphor for the criminal intentions each is hiding from the other.

Waters' use of the gothic follows trends in recent scholarship. According to Francis O'Gorman: 
the trend against realism in the 1980 s led to a renewed study of the Gothic, especially the writing of ideology on the body. Kelly Hurley (1996) ... accounted for the resurgence of the Gothic during the fin de siecle and examined a key scenario that haunted gothic fiction: the loss of a unified, stable human identity, and the emergence of a chaotic and transformative inhuman identity in its place. $(2002,10)$

In Waters' novel, the primary way in which the fairy-tale transformation takes on dark, gothic tones is that the two narrator-heroines become villains of the other's story, losing their identities in the process. Maud and Sue undergo transformation from child-like ignorance and naivety to adult self- realisation and awareness. Sue and Maud remain unaware of all the facts until the novel's end. Characters are described as innocents and fools (Charles, Briar's house boy is literally). Sue is: "slow" (14) while Maud is a: "dummy" (36-7) and is thought childlike or girl-like by Sue $(89,93,95)$, like Laura Fairly in Wilkie Collins' Woman in White. Part of the transformative, inhuman identity that O'Gorman ascribes to the Gothic is present in Waters' imagery which links her characters with non-humans, inanimate objects or quasi-supernatural concepts.

Waters uses the imagery of fate, chance and magic which all offer transformations of fortune for better or worse. Thieves are "better than magicians" (8). Or they are characters from a deck of cards: Mr Lilly is King of Diamonds, Gentleman, Jack of Spades, Maud, a Queen (23-25). Maud tells Sue her grandmother was a gypsy-princess (98) Maud disdains this story, claiming: "You are too fair in the face" (100), a clue to Sue's elite origins.

Jewellery imagery suggests the economic value of characters. Sue regards Mrs Sucksby's treating her as a jewel as a sign of love, as she is of ordinary face and talent (12). Gentleman, who wears "counterfeit jewels" (18) claims of Maud: "She's our little jewel, Suky. Soon I shall prise her from her setting and turn her into cash" (114). Maud leaving Briar is "like a pearl coming out of an oyster (79). Mrs Sucksby says of the note left in her care which Sue's mother addressed to Susan Lilly on her eighteenth birthday: "Kept this closer than 
gold!" (338).

Animals and food are interrelated sinister metaphors in Fingersmith, suggesting human frailty and the possibility of devourment by the enemy and uncertainty about whether a character is predator or prey. Maud is a "tabby cat" (180), harmless looking, yet a predator, but also prey, a "veal calf" (182), a "pigeon" and a "chick" (66). Maud's naked body is "soft as butter"(83) but this is disarming as her tooth is sharper than a serpent's (97). Sue meets Maud in a room with "a dead snake in a glass case with a white egg in its mouth" (65), a symbol that the erstwhile predator, Sue, will become the victim of her ambition. Sue is a snider at the rentrenf. Gentleman's weh nfamhition. (128), Sue realises. Maud has tricked her. Sue's leaving supper is a stuffed pigs head, "its snout gummed brown with treacly tears". Sue's mood mirrors the pig's tears: "I grew sad" (ibid, 43). This symbolises that she is prey, like the pig. Maud won't eat the bloody offal she is served, so Sue does (164-165) which is suggestive of a role swap which will disadvantage Sue.

As Waters uses more than one literary style, this is in itself transformative of the text and of our reading experience. At the conclusion the story escapes from the confines of the gothic into the 'light', or the revelation of Sue and Maud's true selves, as in a bildungsroman or 'coming of age' novel. Their respective losses of identity and position are equalised by their relationship and sharing of wealth at the end of the novel. The transformations have ceased and their identities have stabilised into a melodramatic happy ending.

As I have argued, Waters uses Victorian literary models. Dickens and Waters share subject matter and treatment. Dickens wrote about the underclass, petty criminals such as thieves and pickpockets are features in various of his novels. Fingersmith, like Great Expectations is also bildungsroman or character biography featuring a first person narrator reminiscing their search for love and a career. Fingersmith and Dickens' Little Dorrit feature prisons. Sue's description of the "drop to the pit" at Oliver Twist is reminiscent of hanging. (Fingersmith, 3-4) Our Mutual Friend features the East End underworld and squalor, gothic, 'murder', double crossing, faked identities, and a great fortune 
with conditions attached and a rakish gentleman planning to seduce an innocent woman. Dickens' female characters die innocent or redeem themselves by dying if they fail the ideal, for example, Esther's mother in Bleak House. This is like Fingersmith's Mrs Sucksby who behaves questionably as a maternal figure, and redeems herself by taking the blame for her daughter Maud's murder of Gentleman and dies on the gallows and Sue's heiress mother who bore her out of wedlock, and dies in a mental asylum.

Waters' narrative in Fingersmith is also Dickensian: "Like Dickens, Waters employs a complicated plot" (Jay 2002). Oliver Twist is a workhouse boy who falls into the clutches of London's criminal underworld. Fingersmith's upper class orphan heroine is abducted by petty thieves and baby farmers. Fingersmith is also a detective story. Sue discovers her real mother and origins, like Esther in Dickens' Bleak House, who discovers that she is the illegitimate daughter of an aristocrat, Lady Dedlock. The theme of aristocratic women navigating threatening urban geographies is found in both Bleak House and Fingersmith. When Lady Dedlock enters the city at night, she risks identification with underclass women. (Deborah Epstein Nord 38-59, 53, in Smith 124). Maud runs this risk after she escapes Mrs Sucksby's house and flees into the London streets, experiencing the meanness of the inner city and the sexual risk towards unprotected women (369-375).

Maud and Sue work within domestic settings and narrate their own stories, meaning we see events from their perspective, which partially empowers them. This female empowerment is also like Bleak House. In Daughters of the House: Modes of the Gothic in Victorian Fiction, Alison Milbank, following Ellen Moers, describes Esther's optimistic, questioning narrative as female gothic and the fatalistic, accepting, third person narrative as male gothic (Smith, 124-5), thus gendering the mystery. Radcliffean (notably female) Gothic underpins Victorian Gothic and the work of Dickens and Wilkie Collins, and Bleak House is Dickens' version of this, centering around the relationship of Esther and Lady Dedlock and their problematic relationship with domestic spaces (Smith 124-5). Esther's narrative control is suggested by her writing, and her domestic ordering demonstrates her agency and this marginalizes the pessimistic male narrative 
(Millbank, 95). Fingersmith's heroines also have problematic relationships with domestic spaces, which are imprisoning and full of threats to sanity and self.

Waters reflects Dickens criminal fiction as in Oliver Twist. Dickens described capital punishment in his work, such as that meted out to Fagin in Oliver Twist. In Fingersmith, Mrs Sucksby is a Faginesque corruptor of innocents, and she is also publicly hanged. Sue's mother was hanged as a murderess:

The job that was meant to make her fortune, had gone badly. A man had been killed trying to save his plate. It was my mother's knife that killed him. Her own pal peached on her. The police caught up with her at last. She was a month in prison. Then they hanged her. (11-12)

Mrs Sucksby is a bad character who, in Dickensian style, in not entirely unsympathetic:

... I began to scream, and Flora could not quiet me. ...She took me home, and Mrs Sucksby slapped her.

"I don't hire my infants out to have them brought back like this, turned blue with screaming. What was you playing at?'

She took me upon her lap, and I wept again. 'there now, my lamb,' she said. Flora stood before her, saying nothing, pulling a strand of hair across her scarlet cheek. Mrs Sucksby was a devil with her dander up. $(3-4)$

Fingersmith's connection with Oliver Twist is extended by Sue's confusion of the theatre version with reality. In Fingersmith's description of a performance of a play version of the novel, when Bill Sykes strikes Nancy dead, Sue fears "we should all be killed" (3-4). Sue remains afraid Bill Sykes will find her. Mrs Sucksby treats him as if he were real, but assures Sue: "Why, he's a Clerkenwell man. He don't trouble with the Borough. The Borough boys are too hard for him" (5). She claims that Nancy lived, and was in her shop an hour ago, she had left Sykes and "she had met a nice chap from Wapping, who had set her up in a little shop selling sugar mice and tobacco" (6). Sue is brought to her senses by 
Mr Ibbs' 'sweet whistling' and his kindness:

....and I remember seeing - what I had never seen before - how the world was made up: that it had bad Bill Sykeses in it, and good $\mathrm{Mr}$ Ibbses; and Nancys, that might go either way. I thought how glad I was that I was already on the side that Nancy got to at last. - I mean, the good side, with sugar mice in. (7)

However, years later, she sees Oliver Twist again, and realises that Nancy was murdered. Flora, "poor thing", is caught and transported as a thief (7).

Like Dickens, Fingersmith's character names are comic, eccentric or describe character, such as former lady's maid Dainty (28) or Charley Wag, the dog (16). "Christopher Lilly" (32) ironically suggests purity and Christianity. "Mrs Sucksby" suggests the words 'sucks baby' and therefore her role as a baby farmer. Sucksby also suggests succubus and her partner in crime, Mr Ibbs, an incubus.

Wilkie Collins' Woman in White is the most important literary source in Fingersmith's narrative and literary style. Woman in White is a sensational, gothic detective story based around the interrelated mysteries of gender and identity. According to Sweet:

The Woman in White is generally regarded as the first sensation novel, an enormously influential branch of Victorian fiction which fused the apprehensive thrills of Gothic literature with the psychological realism of the domestic novel. Using a high-impact style of narrative that put its characters through a series of extreme mental experiences, Collins and his imitators... brought the terrors of the Gothic novel down from the mouldering Italian castles and into the back parlours and drawingrooms of a recognizably modern, middle-class Victorian England. Their dark plots - which usually hinged on murder, madness, bigamy or all three - were hatched in contemporary country manors and on brand-new suburban housing developments. (xiii) 
Construction of identity is The Woman in White's major theme, as in Fingersmith. Laura Fairley's new husband, Sir Percival Glyde, plots to steal her fortune and identity and confines Laura to an asylum (in which he has previously imprisoned Laura's probable half-sister Anne Catherick who threatens to reveal that he is illegitimate and not entitled to his peerage). Waters uses that basic plot. In Fingersmith, Maud's new husband, Gentleman, also plots to steal her fortune and identity. The difference is that in Fingersmith, it is a double - cross. The husband's conspirator, Maud's ladies' maid Sue, is confined to the mental asylum, under Maud's name. Sue is the real heiress, as she and the unrelated Maud, were switched at birth by baby farmer Mrs Sucksby.

The Woman in White begins with Walter Hartright, who is due to depart London to become teacher of drawing to Laura Fairley at a stately country house, Limmeridge, walking on Hampstead Heath, when he is approached by a woman wearing a white dress who asks him the way to London. (63). Walter meets the anonymous woman after she has escaped wrongful incarceration in an asylum, like Fingersmith's Sue. As he questions her identity, he questions his: "Was I indeed Walter Hartright? (Collins, 1985). Later, at Limmeridge, he and Laura's half-sister Marion Halcome identify the woman as Anne Catherick (63). Walter sees Laura in Anne's face:

I had seen Anne Catherick's likeness in Miss Fairlie. I now saw Miss Fairlie's likeness in Anne Catherick...If ever sorrow and suffering set their profaning marks on the youth and beauty of Miss Fairlie's face, then, and then only, Anne Catherick and she would be the twin-sisters of resemblance, the living reflexions of one another. I shuddered at the thought... 'You are looking at me; and you are thinking of something,' she said... 'Nothing extraordinary' I answered.' (Collins, 1999, 96-97)

This passage is reminiscent of Fingersmith's Mrs Sucksby looking into Sue's face and claiming to see Sue's dead mother in it. Sue thinks that Mrs Sucksby is actually seeing her dead baby: 
'I see her in you', she'd say. ...'Poor girl, she'll never come back! Your fortune's still to be made. Your fortune, Sue, and ours along with it...' I let her think it; but thought I knew better. I'd heard once that she'd had a child of her own, many years before, that had been born dead. I thought it was her face she supposed she saw, when she gazed so hard at mine. The idea made me shiver... (13).

The identity of the mother in Fingersmith is both confused and tarnished. Sue continually misses narrative 'clues'. She is puzzled Maud keeps her portrait of her mother locked in a box (73). Maud herself does not recognise that it is her mother who is going to the gallows explicitly for the crime of murdering a man, but implicitly for her sins as a bad mother to both Maud and Sue and the infants in her care. This has Victorian antecedents in literary depictions of the bad or absent wife and mother who repents although it is too late- her good character and therefore domestic and public identity has been altered permanently for the worse. Nina Auerbach writes in "Before the Curtain" (in Powell, ed.): "East Lynne [and the 1874 play by T.A. Palmer based on the novel by Ellen Wood] is a cautionary account of a runaway wife, but it is also a kaleidoscope of unstable domestic identities: the only permanent structure is the stately home East Lynne itself' (11). Lady Isabel's final incarnation is as an unrecognized servant until she reveals her identity on her deathbed:

"Isabel's eulogy is less a eulogy for her son than for her own lost roles: 'Oh, Willie, my child dead dead dead! And he never knew me, never called me mother!' (Act III). Mother is a matter of class and clothes; when the accoutrements vanish, so does the being." (12)

Such depictions were the cautionary tales seemingly aimed at any woman who might considering abandoning the Victorian female's expected domestic role of 'angel of the house'. Fingersmith's Sue is, in fact, the illegitimate daughter of an heiress, Marianne, a self-described ruined woman, another Victorian cautionary literary archetype: "you tell me this: what does being a lady do for you, except 
get you ruined?" she asks Mrs Sucksby, at whose house she gives birth (332). Marianne is essentially a "fallen woman" because she was in a respectable position before she was ruined (see Nead, 349). This is similar to Lady Dedlock in Bleak House, who conceals the fact she had an illegitimate daughter, Esther, before she married into the aristocracy. Like Lady Dedlock, Fingersmith's Marianne Lilly has failed at being a good mother simply by conceiving out of wedlock, then, symbolically, by dying. Mrs Sucksby abandons Maud, an infant in her care, to Marianne's evil father and brother, by swapping her with Sue. This is not just because of the eventual financial rewards Mrs Sucksby hopes to reap, but because Sue's mother begged her to take her, because she didn't want her raised by her father and brother (332-335).

According to Francis Gorman, contemporary feminist critics have argued that sensation fiction was used to critique Victorian gender politics in a way that would have been less possible in the more respected realist genre (9-10). In Woman in White, Marion Halcome complains about the injustices done to women. As in Fingersmith, a female character in Collins' Woman in White is also falsely committed to a mental hospital because of the greed of those that want her inheritance.

Marion Halcome and Walter Hartright, the drawing master whom Fingersmith's Gentleman references, exchange gender roles. Sensation novelists Dickens, Collins and Doyle were concerned with the erosion of male power (Smith, 127). Marion, whom Collins describes as "masculine" (58-9 in Smith, 126), is the principal detective in the first part not the feminised Walter Hartright (Smith, 126). Fingersmith's Maud contradicts gender scripts by being a pornographer, not a sexually innocent young lady, but acting the part, to seduce Sue.

In the sensation novel, women are presented as the innocent sexual victims of predatory males. The innocence of the victim is contrasted with the evilness of the intentions (87-88). In Woman in White, Laura Fairly is also a sacrificial innocent to Sir Percival Glyde. Also, Sue observes Maud's: "pale” reluctance to get married, and assumes it is because she doesn't: "want" Gentleman (130- 
131). In Woman in White, Marion Halcombe observes a similar illness and reluctance in Laura Fairly towards Sir Percival Glyde. Laura goes to her marriage as if going to her doom (194-195). Bad omens include a sprig of dried leaves as Maud's wedding flower, the flint church, black in the moonlight with yellowed whitewash interior, with dead moths in the few lit candles (155-6).

The Woman in White has aspects of the detective story, a genre which becomes popular during the second half of the $19^{\text {th }}$ Century. One of the most popular characters of detective fiction is Sir Arthur Conan Doyle's Sherlock Holmes. Arthur Conan Doyle's arch criminal, in the Adventures of Sherlock Holmes (1892) is the (increasingly degenerate and demonised) middle class male (or gentleman) who shirks, abuses or compromises his responsibilities (Smith 129). This characterises Gentleman in Fingersmith who transforms from a bejewelled rake (18) into a clean-cut, modestly attired "handsome, nice-minded gentleman" (105) to trick Maud. Mr Lilly is demonic, with dark, ink-stained hands, hard, pointed, blackened tongue and green glasses (75). White features similar evil or selfish male characters: Count Fosco, Sir Percival Glyde, Mr Fairlie. Also a teacher of drawing, Fingersmith's Gentleman is the degenerate version of White 's Walter Hartright.

Class is implicated in the Victorian novel's treatment of gender and identity and this is reflected in Fingersmith. In Doyle's Holmes stories, the mystery of identity is the preserve of the middle classes (129). According to Rosemary Jann in "Sherlock Holmes Codes the Social Body" only they can successfully fake identity (Smith 129) while working class criminals are detected via physiognomy. (Jann, 1990, 685-708, 693 in Smith, 129): "The common thread...seems to be that women in general (like the lower classes) have less control over their emotions" and hence are less able to deceive (Jann, 697 in Smith, 129). In Fingersmith, Waters contradicts, to an extent, this Victorian convention. Sue successfully fakes an identity as Maud's maid, and controls her emotions toward Maud sufficient for Gentleman to carry out his deception. However, as Sue is revealed to have upper class origins, this may explain her self control. 
The literary mode of sensation affects geography, landscape and domesticity. Holmes informs Watson in The Adventure of the Copper Beeches that the country is more criminal that the city, because it is easier to conceal crime there (323 in Smith, 132-133). Fingersmith's Briar, the mansion in which Maud lives, is a house of pornographic sin. The most sinister aspects of Collins' White take place in a countryside mansion. Like unwelcoming Limmeridge (33) or Blackwater Park (197) in White, Fingersmith's Briar is the sinister country mansion "that I must now call my home" (56-57). Maud and Sue visiting the grave of Maud's mother by Briar's onsite chapel is reminiscent of Walter Hartright meeting Anne Catherick at the grave of Mrs Fairlie (Collins, 1985, 8896): "For at the chapel there were graves, of all the Lillys that had come before" (78-79) suggests a long string of virgin female sacrifices. Dickens' Chesney Wold in Bleak House represents aristocratic decline, echoing arostocratic moral and physical decay (Smith, 2004, 124).

Extreme physicality and emotions are key aspects of sensation and Waters follows this convention (Sweet, xvi-xvii). Maud recalls: "A strange bare girl had once run, shrieking, down Lant Street, with a policeman and a nurse behind her. Suppose Miss Lilly took fright like that, and I had to grab her?" (36). Walter meets Anne while she is running, terrified, from asylum officials (2331). Maud's brutal version of her birth and her mother's death scene is reminiscent of Frankenstein. Maud's mother, strapped to a table, is more malfunctioning machine than human, accompanied by the beating of clocks and the dripping of blood (179). Sensational revelation in a novel's narrative, or by its characters creates a "hysterical tempo" (Sweet, White, xvi). Sue realises she has been tricked when doctors pull from the coach: "He held out his hand. He held it out to me" (173). Maud reveals her love for Sue, despite her betrayal: "My own poor mistress. Oh! My heart is breaking!" (168-171). Maud claims: "For it was my birth that killed my mother. I am as to blame for her death as if I had stabbed her with my own hand!" (122). Such extremes are ripe for parody. Like Jane Austen's Northanger Abbey, Waters attempts comic satire of the gothic, when what terrified Maud thinks is a burglar turns out to be a "quivering" crinoline (86-88). 
Fingersmith has elements of both melodrama and a morality tale, both staples of Victorian literature. Melodrama is an emotionally based theatrical or literary response to an unjust, cruel, inexplicable universe (David Mayer in Powell, ed, 148). It validates the experiences of the most helpless and vulnerable (see Martha Vicinus in Fisher and Watts, eds, pp 174-186 in Powell, ed, 148) by explaining the world in simple, Manichean terms - a battle between good and evil, where characters are never morally complex (148). Both melodrama and morality tale offer a happy ending for deserving characters who must first brave perilous situations that offer constant threat of ruin.

Sad endings are falsely proposed: Sue believes that Maud is a reluctant bride: "She was about to be married, and was frightened to death. And soon no-one would love her, ever again" (156). Of course, Maud finds true love by novel's end. Happy endings are also falsely proposed. Mrs Sucksby lies to Sue that Nancy survives in Oliver Twist and tells Sue that her mother died a quick, painless death on the scaffold - a story that has to be open to conjecture (48). Similarly, Maud marrying Gentleman and retiring to London with Sue (126) is a false proposal, but this does not preclude the ultimate, deserved, happy ending. Sue appears to have undergone a moral transformation: "“You leave her alone,' I said. ...'Oh, Suky,' he said, 'have you grown squeamish? Have you learned sweet ways, after your spell with the quality?"' (129)

Prostitutes and fallen women were often fated to unhappy endings even in melodrama, and their fates provide a warning contrast to the happy endings of more virtuous characters. According to Linda Nead, while the terms 'prostitute and 'fallen woman' frequently overlapped, a fallen woman was a respectable woman first, not a working-class prostitute. Her seduction and betrayal made her a victim, devoid of power and independence. Her deviancy did not involve money and she retained her femininity (in Boyd and MacWilliam, 349). Sue's mother is revealed to be a fallen woman and dies in a mental asylum. In Bleak House, Lady Dedlock is a fallen woman and dies. However, Maud doesn't fallnever consumating her marriage to Gentleman. In the Victorian novel she would not be excluded from the possibility of a happy ending. 
Slips in morality cross generations. Sue responds to taunting about her criminal mother: "I took up a pair of kitchen shears and put them to his neck. I said, 'Bad blood carries. Bad blood comes out"(80). This is ironic, as Sue is ultimately revealed to have aristocratic blood, but true as there are murderous consequences for other underclass (or erstwhile) characters. This generational morality slippage threatens a happy outcome, but in this case, perhaps because the first sin was not Sue's, it does not ultimately condemn her.

In Fingersmith, Waters demonstrates an awareness of lesbian history - and of the presence of pornography in Victorian literature. Sexuality was a crucial axis of power and control in Victorian society and moved to centre-stage in Victorian Studies in the 1980s and 1990s (Boyd and MacWilliam, 339-340). Waters reflects these research trends, generally, in her novel, and specifically in its treatment of pornography and lesbian history. Karla Jay writes: "Fingersmith... is relatively chaste... Waters appears to be reflecting the social constructionist view that women prior to the late 1850's lacked a language for same-sex love. Sue and Maud have no words for their attraction. 'Like it, do you?' one might say, but there are no terms to define the 'it' in question" (39). According to Michael Bronski:

This [Victorian] obsession/denial of sexuality gave rise to a large scale pornography industry. And while much has been written in recent years about hard-core, sexually explicit Victorian porn (The Lustful Turk, A Man and His Maid) the reverse side has gone largely unexplored. This sentimentalized soft-core - not explicit but with a sexual subtext - porn catered to the safe, clean imaginations of the Victorian mind. Even if there was some inkling that their attraction was sexual it could immediately be denied since children (and of course, women) were ipso facto not sexual. (1)

In Fingersmith, Waters creates a hybrid. She has a literary flirtation with the conventions of Victorian hard-core pornography, but ultimately explicitness is 
tempered by romanticism. This continues a tradition which Waters began in Tipping the Velvet which included pornographic descriptions but is ultimately a romantic love story. Affinity has quasi- sexual sado-masochistic imagery and intimations of spiritualist sexual assault but doomed heroine Margaret remains hopeful of a romantic conclusion until she is disabused of that hope at the novel's end. Waters strongly reflects gendered conventions of pornography, both Victorian and contemporary. Female pornography is 'nice'. As a ladies maid, Sue sees Maud naked, but it is a positively chaste experience, and neither is contaminated: "My gaze was nothing to her. ... she was as pale as a statue on a pillar in a park. ... she seemed to shine" (83). Maud and Sue sleep together like sisters until Gentleman's corrupting arrival (89). Sue has intimations she is falling in love with Maud (136). Sue accidentally seduces Maud on the pretext of impersonating Gentleman (139-142). She is a proxy who doesn't own her sexuality. Sue teaches Maud how to dance: "I am the gentleman, remember. Of course, it will go much better, with a real gent" (95). Maud questions Sue about what Gentleman will want to do with her and tricks her into kissing:

\section{'So you feel it?'}

The words sounded queer; as if the kiss had done something to my tongue."

...She began to shake. I supposed she was still afraid. Then I began to shake, too. ... 'You pearl,' I said. So white she was! 'You pearl, you pearl, you pearl.'

...The shiver was a ghost of the shiver that had seized me - seized us both - as I'd moved against her, in the night. Being fetched, the girls of the Borough call it. Did he fetch you-? ... I put the tip of one finger to my tongue. It tasted sharp - like vinegar, like blood.

Like money.

I grew afraid. (138-145)

The pearl was a strongly established Victorian pornographic symbol (John Woodrow Presley, 1996). The sex itself is portrayed as innocent, it faces corruption from external elements such as 'male instigated' avarice. Male 
explicit pornography is about deliberate corruption- the drawing master who seduces his pupil (25) and the lowest common denominator. As Gentleman says of Maud "'She is afraid of herself. Girls like her always are. But let them squirm and be dainty as much as they like, they all want the same thing in the end.' $\mathrm{He}$ paused, then laughed. He thought it a filthy kind of joke" (133).

In her acknowledgements to Fingersmith, Waters acknowledges the influence of Victorian erotic and pornographic fiction: "Christopher Lilly and his index is based on Henry Spencer Ashbee and his bibliographies. His [Lilly's] statements on book collecting are Ashbee's but he is otherwise fictitious. All texts cited by Maud are real" (Endnote 1). According to Andrew Lycett in "Erotic Heaven", a review of Erotomaniac: the Secret Life of Henry Spencer Ashbee (New Statesman, March 12, 2001) Ashbee was “a typical, dutiful Victorian" businessman: "Behind this façade he was an obsessive collector and cataloguer of erotic literature." Christopher Lilly hides behind a similar facade, that of a proper Victorian scholarly gentleman.

Some Victorian women wrote erotic fiction, and Maud and Sue appear to be their literary offspring. Maud is a New Woman - a Victorian emancipated woman, because she is well educated in literature, a professional secretary and sexually adventurous. Evolving from Victorian 'female sexual innocents', Maud and Sue (who are physically, if not intellectually innocent), gain sexual agency. At novel's end the heroines' new career is writing pornography.

\section{Conclusion}

Of Waters' novels, Fingersmith is the one in which narrative assumes the greatest importance and where she borrows most heavily from a Victorian literary plot. It is also the novel in which there are the strongest references to storytelling within the text. Waters' academically aware references to Victorian pornography also make Fingersmith distinctive within her own novels and within historical fiction as a whole. 


\section{Endnotes}

1. In her acknowledgements for Fingersmith, Waters writes:

The index upon which Christopher Lilly is at work is based on the three annotated bibliographies published by Henry Spencer Ashbee under the pseudonym Pisanus Fraxi: Index Librorum Prohibitorum: being Notes Notes Bio - Biblio - Icono - graphical and Critical, on Curious and Uncommon Books (London, 1977); Centuria Librorum Absconditorum being Notes Bio-Biblio-Icono-graphical and Critical and Uncommon Books (London, 1879); and Catena Librorum tacendorum: being Notes Bio-Biblio- Icono- graphicical and critical, on Curious and Uncommon Books (London, 1885). Mr Lilly's statements on book-collecting those of Ashbee, but in all other respects he is entirely fictitious.

All of the texts cited by Maud are real. They included: The Festival of the Passions, Memoirs of a Woman of Pleasure, The Curtain Drawn Up, The Bagnio Miscellany, The Birchen Bouquet, and The Lustful Turk. For publishing details of these see Ashbee, above. (349) 
The Night Watch: "Colonel Barker was Mr Mundy's name for her". Unlike Waters' previous novels, which were set in the Victorian era, The Night Watch is set during and post WWII. In The Night Watch the chronology is reversed. The novel opens post WWII, in 1947. The main characters are Kay, an ambulance driver during the war, now unemployed, Helen and Julia, whose relationship is foundering, Duncan, who was imprisoned during the war for his involvement in his friend Alec's suicide, and now lodges with Mr Mundy, his former prison guard, Fraser, his middle class concientious objector former cellmate, and Viv(ienne) Pearse, Duncan's sister. These characters are still living with the aftermath of events during wartime and struggling to redefine their lives in this new era. This is particularly true of female and lesbian characters who enjoyed the freedoms that wartime gave them, which are portrayed in the book's second and last sections, 1944 and 1941, and found these rescinded in peacetime. It is also true for Duncan, liberated from prison but still metaphorically imprisoned by his own thoughts, socio- economic constraints and the sexual designs of Mr Mundy.

Waters' attention to the details of Victorian society and literature is matched by her attention to that of WWII. Thematic continuity is strong as Waters examines the same issues in both eras: aspects social and cultural change, particularly as relates to gender and sexuality, class stratification and mobility.

The novel reflects war-time conditions. Waters' text keeps close to the reality of the experience of Londoners during the Blitz. "Between October and December 1940, London was bombed every night" (Sheridan, 96). The experiences of war besieged Londoners were recorded in the Mass Observation Archive, (19371955) (Sussex University, 2007). This was an official social history project which involved ordinary people contributing diaries of their experiences, including during wartime. Sheridan's Wartime Women: A Mass Observation Anthology 1937-1945, which Waters cites in her acknowledgements for The Night Watch includes a diary by a women ambulance worker. (96-109). In addition to secondary sources, living testimony is still available, which The Night Watch echoes. My paternal grandmother, Bobby Robinson, who was living in London during the Blitz claims she took " no notice"” of the bombing 
and continued socialising. Her boyfriend pushed her into the gutter, to avoid an explosion (Endnote 1)- luckier than the couple in The Night Watch (412-413) who do not let the war get in the way of their socialising, and get killed by a bomb on the way back from a party. Bobby Robinson also swept incendiaries off roof tops, which in The Night Watch is a task Julia mentions elderly men doing (336).

Conscientious objectors to military service were frequently imprisoned during wartime. Waters is sympathetic, in keeping with post-war pacifist movements, but not entirely revisionist in attitude towards their plight. Frasers feels "[s]ick, for being healthy... for being alive" (84). Duncan's Father is ashamed his son is not fighting, and Duncan is angry that his father wants him to become a "murderer" (310-311). The only character who is a soldier, Viv's cowardly boyfriend Reggie, abandons her at the ambulance (383).

In Women at War (1990), which Waters cites in her Acknowedgements for The Night Watch, Phyllis Pearsall writes: "Most books about war are by, for, and about men" (7-8). Pearsall's eyewitness drawings "record women in their uniformed and civilian occupations", their "humour and fortitude" and "comradeship and committment" (Jacket). Pearsall describes ARP Ambulance and Fire Stations (60-67) such as Night Watch's Kay works at. Pearsall records women war workers' good humour. Pearsall's record is reflected in interactions between ambulance workers in The Night Watch. Pearsall's work has a celebratory nature, which The Night Watch shares: "The mood of the place began to grow jolly. It was a sort of exhilaration, at having survived, got through, taken on another raid and beaten it" (196). However, by contrast, Waters also introduces believable workplace conflict when Kay and Mickey are told off for not following procedure and Kay makes a smart response: "You'd like me to leave a street to burn and bring more bombs? We'd have lots of jobs, then" (193-7).

War and post-war gender, including lesbian and gay society, are important themes for Waters. WWII was a time of pride and heroism, still a "national preoccupation", in Britain and elsewhere, with feminist interest in female 
heroism and liberation and how women were expected to return to domestic roles and feminine dress after the war (Sheridan, ix). Waters is influenced by this research trend, as her female characters are war-time heroes who lose their jobs after the war. Waters incorporates the gay and lesbian community in to this narrative and particularly shows how the post-war period was particularly restricting for lesbians, who no longer had the social freedom to wear practical, masculine clothing without comment, and who, as single women, still had to support themselves financially. Viv mistakes Kay and Mickey for boys (382). After the war, Kay maintains this androgeneity $(3,5)$. This creates a kindred association with androgynous Duncan: "He liked the bold cut of her hair, her mannish clothes... ‘Colonel Barker' was Mr Mundy’s name for her” (6). Kay's lack of post-war femininity is a sign of madness and she is made fun of in a shop (94). Wearing masculine clothing renders Kay and Mickey, as lesbians “grotesquely visible" (cf. Kay quotes H.G. Well's Invisible Man, [96]). Characters suffer from contemporary gender expectations. Viv and Betty discuss illegal abortion methods and dismissal from work for pregnancy (274). Morning-sick Viv is "“the Ghost of Typists Past"” (351). Viv attempts to hide her unmarried state and the abortion from Kay, at risk to her life (377-386).

The author of the eponymous Journals of Denton Welch, cited by Waters, was a young gay aesthete of the 1940s, physically frail, feminine, like Duncan Pearce. Welch admired examples of healthy masculinity $(40-41,49,86)$, similar to Duncan admiring Fraser (39). The societal definition of healthy post-war masculine sexuality was heterosexuality. Men who were homosexual were regarded as ill and it was believed this was manifested in femininine characteristics and intellectualism. Waters reflects those social perspectives, not revisionist ones. The most feminised male in The Night Watch is the most unpleasant, the transvestive Aunty Vi (215). Because Fraser has been imprisoned for concientious objection, which was perceived as cowardice, an un-manly trait, and because he is caring towards Duncan, a boy outside his own class with whom he was not expected to be friends, he risks being perceived as homosexual. Viv is suspicious of Fraser's intentions to Duncan, but "there is a list of girls who could put you straight" (120). The Night Watch reflects that gay relationships were closeted. Duncan is reluctant to "say Goodnight", a sexual 
euphemism, to Mr Mundy (151). Duncan refers to Mr Mundy as his uncle (7). Their sexual relationship is also described in sinister metaphors:

Duncan was lying on his stomach on the hearth-rug with an open book before him, and in the small of his back sat Mr Mundy's little tabby cat. The cat was working its two front legs as if kneading dough, flexing and retracting its toes and claws, purring ecstatically. Catching sight of Viv, it narrowed its eyes... (23)

The term lesbian is never used, although "Sapphic" is (241): “I didn't know she was - well,' Helen lowered her voice, 'like us'” (55). However, there is nothing vague about descriptions of sex between Helen and Julia (390-4). The way that the characters view lesbian relationships also reflect 1940s heterosexual perspectives, not later 20th century feminism. Kay "wants a wife" because she's a "gentleman". (396-397). Relationships are closeted: “Other people... had chars. They couldn't do that, because of the business of sharing a bed" (47). Julia's affair with Ursula Waring reflects Barbara Bell's affairs in wartime autobiography Just Take Your Frock Off, which Waters cites. Bell flatted with girlfriend, fellow policewoman, Madeleine (68-71), just as Night Watch's Helen and Julia also live together. Bell describes lesbian clubs, butch and femme roles and dress codes (71-3) which have some reflection in Waters' novel. Bell recounts how she cheated on her girlfriend, Madeleine (89-90) just as Julia has an affair with Ursula in Night Watch.

In Bell's autobiography, Bell narrates her career as a young woman during WWII as a policewoman, a not dissimilar role to Night Watch character Kay's ambulance driver, and both uncommon roles for women. Both had public responsibility for the well-being of civilians. Bell also depicts her post-war unemployment. The nature of life during war-time, and its physical, material psychological trials is described from a lesbian perspective, including relationships and sexuality. Bell describes the respect the public had for her police uniform and the confidence it gave her (60). Bell's psychological response to life and work in war was as follows: 
It was life on a knife edge. You didn't know if you were going to be bombed next time, or even if you were going to come home when you went out. Now when I think, I don't know how I did it. It was pretty awful. ...Seeing a dead body or a few bodies with pieces off them lying about, you don't store it up. At the time you were filled with compassion or filled with horror. You had a good cry and then, next day, it all happened again and you stopped having a good cry, you took it. ...You just thought - well, this is a war, get on with it. We didn't really have much time, too busy looking after other people...You were so intent on helping in some way. If you'd a bit of spare time you enjoyed it. You didn't sit around fretting. ...You might not have liked some of the things you saw, but it was exciting because you never knew when you went out what you were going to come across. It was the swarm and swirl of wartime... You didn't plan for the future. (7879)

Ambulance driver Kay faces a: "grisly" job when a Camberwell house falls on its occupants and she has to put splints on a screaming child's legs (194). More prosaically, Helen works in Marylebone Town Hall's Damage Assistance Department. (14, 262-263), Julia, as a building assessor. As was common in WWII, all the female characters in Night Watch are employed, but fired when "priority was given to demobilised men" (Sheridan, 193). Bell experiences post-war "limbo" when she leaves her police career (Frock, 94) which corressponds to Kay's experience in Night Watch: "I've got lost in my rubble, Mickey. I can't seem to find my way across it. I don't think I want to cross it, that's the thing. The rubble has all my life in it still" (100-102). Duncan thinks of Kay as “one of those women... who'd charged about so happily during the war, and then got left over" (6).

Class tensions are a staple of English literature and Waters reflects this in The Night Watch. Wartime community spirit was superceded by a post-war reassertion of separation and growing working class resentment both in the novel and in reality. Viv takes elocution lessons to get a typing job in the Ministry with middle class girls (230). Discovering her pregnancy, Viv thinks: 
"This is what happens to people like me. I'm just like Duncan, after all. We try to make something of ourselves and life won't let us, we get tripped up" (270). Middle class Fraser mimics the post-war welfare state, acting as a social bridge, offering Duncan and Viv the hope of self-realisation. Speaking with Helen, whom she works with at the dating agency, Viv says "I wanted to be a solicitor's secretary"' (15), a professional middle class occupation she has failed to realise. Fraser's desire to walk with her indicates not just his concern for Duncan but his attraction to her, which offers the prospect of a middle class marriage for Viv, who still has erstwhile boyfriend Regi 's false wedding ring in her pocket (122). Viv is resistant to Fraser's attempt to befriend or partner her, ostensibly because of class resentment. Viv "recalled his brash publicschoolboy's laugh...Duncan... thought anyone marvellous who could talk cleverly, in a well-bred voice" (117). However, despite Viv's attempts to dissaude him from walking with her "[a]s they headed back to Oxford Street...they looked like a couple-a simple, nice-looking, young courting couple" (122). Fraser shows that he is comfortable with her being working class, and with moving in those circles, while offering himself as a gentleman who can protect her from them: "He said, 'Where the hell are you making for, anyway? Your evening job in a leg-show...You'll find me a broadminded sort of bloke. I could sit in the audience and keep off the rowdies...I couldn't think of myself as a gentleman, and leave you on your own in streets like these"” (123). She denies there is anything wrong with Duncan working in a factory as her father did, but wavers in her certainty (120-1). Fraser argues that Duncan living with $\mathrm{Mr}$ Mundy is "peculiar" (121), and argues, truthfully, that Viv feels the same. Fraser insists to Viv that Duncan has to leave the factory and find another job at a bookshop or printers (120-124). He gives Viv confidence, encouraging her to approach Kay who assisted her during the war: "She felt capable of anything!" (131). Jailer and sexual predator Mr Mundy wanted Duncan to have his own cell, ostensibly because Fraser is middle class and "playing at being in prison" (226). Fraser, now a journalist, meets Duncan at the candle factory (38-42). While prison equalised them, class difference is now apparent. Duncan mocks Fraser's middle class idiom: "It doesn't matter what I'd rather. ...I'm lucky to have any job at all..." (82). Money and class are associated with the countryside and healthiness, the working class with cities and illness. Fraser is "tanned" and 
carries "a satchel like a hiker's bag". Fraser has grown; Duncan remains a boy (39). Class difference, symbolised by the urban/ rural divide, is also apparent when Julia, Helen and Ursula meet in a park. Helen's "make-do and mend' contrasts with Ursula's "neat, moneyed, tailored" countryside sports look (53). "Of course, she's more your class than mine... a bit hearty" says Helen to Julia (55).

While WWII is the obvious historical source for The Night Watch, the Victorian influence is an interesting and unexpected aspect of the novel. One connection is that the characters are literally living in the bombed ruins of Victorian London, which functions both actually and symbolically. Waters' use of Victorian influences in The Night Watch is a continuation from her previous successful trio of Victorian novels, which recreate emerging gay and lesbian society in Victorian London, the notorious cultural reverberations of which extended into the twentieth century. The ghostly detritus of Victorian society is ever-present in this novel set in WWII and the descriptive categories applied to Waters' Victorian novels are often eerily applicable.

As with Waters' Victorian novels, transformations, of both character and situation, are Night Watch's most important theme, incorporating social roles such as gender, sexuality and class. War and post-war periods are the perfect catalysts for these. Role swapping of class or character is an important dynamic within Night Watch because it either enables or quashes the human potential of characters. Women's roles transform from domestic workers to public actors, while the principal male characters are passive in prison. Night Watch's principal heroine, Kay, is more 'herself' in war than peacetime. Viv [becomes] "a different girl...neat, smart, guarded" when she leaves her father's presence (Night Watch, 165) Class roles mutate when two boys working and middle class share a prison cell. After prison, Fraser transforms into healthy middle-class grown up who aims to similarly transform Duncan's life (41) Duncan takes the blame for Alec's suicide and goes to prison: "it ought to be that other boy in there, not Duncan!" (165) says Duncan's father, Mr Pearse. When a bomb hits the prison, self assured Fraser becomes a "coward" while Duncan is unfazed (406-9). 
Magic can transform. Duncan's childhood desire was to be a magician until he learned it was "just tricks" (16). Kay and fellow ambulance-woman Mickey are tricked when they try to help a man after a bomb blast, thinking he has just lost a limb: "If you find a leg on the end of that you'll be a fucking magician. I lost that in the last war" (192). Duncan describes Alec's suicide note as "wizard" (451) as if it was part of a magical dissapearing act. Helen feels tricked by Julia, who has revealed that she loved Kay, but Kay didn't love her (ostensibly the circumstances that lead to her being in a relationship with Helen). Her confidence is knocked and she observes moonlit bombed houses are "lit by...lurid sparkles and flares" (398). Moonlight through the blackout curtain creates effects "like spangles on the clock of a stage magician" and Fraser and Duncan become physically closer, sharing Duncan's bed when they experience a bombing raid while in prison which terrifies Fraser (408).

As in earlier novels, Animals and food are sinister metaphors for sexual devourment and human baseness. The behavior of Mr Mundy's tabby cat suggests Mundy's sexual relationship with Duncan. The cat is seen kneeding and clawing the small of Duncan's back, lifting his shirt (23) or licking meat off Mr Mundy's hand (27). Duncan fears being made into a pie, or tinned (28). Helen describes "her pressed-meat thighs, her onion face..." (57). Viv, on the abortionist's couch, is "like a fish, with gaping gills and mouth, on a fishmonger's slab" (ibid, 364). Under the gas Viv dreams she is gored by a “German Bull” (365-366).

References to musical theatre are reminiscent of Tipping the Velvet, and emphasises cultural continuity from the Victorian era. Theatre imagery emphasises both the heightened drama of the characters' wartime lives and the fact that Waters is telling a story, regardless of her attention to historical detail: ““Four broken bones in Warwick Square.' Kay frowned. 'That's a music-hall song, surely?" (195). Helen "paces like a despairing actress" (143), Alec gives a "theatrical" shrug (454), Duncan trains the tabby cat for the circus (23). House fronts are "flat as scenery on a stage" with "trees of papier mache touched up with glitter and silver paint" (360). This imagery creates a sense of 
the unreality of wartime London.

In The Night Watch, Waters uses narratives and characterisation from children's storys and fairytales to emphasise character retardation and entrapment. While living realistic lives in wartime London, characters are menaced by the constricting power of fully-formed narratives into which their developing lives are forced. This mirrors the restricting power of social structures especially class. Duncan Pearce is trapped, as one cursed, in a childlike world. Viv claims: "Poor Duncan...He's in a world of his own, he is" (18). He lives in Mr Mundy's Victorian boyhood room with boy's adventure stories and lead soldiers (152). Duncan appears at Fraser's house, in his pyjamas (157), like a child in Peter Pan. He is "like a boy in a picture - book" (205). Imagination traps Duncan by creating paranoia: "There's no one looking, Pearce" (91), says Fraser, when Duncan thinks he is still being stared at with hostility by pub patrons who know him from his local area of Streatham. Fraser in prison is "like a prince, dressing up as a pauper" (226). His year at Wormwood Scrubs is "a dream plucked out of time" (92). After prison, Fraser is released as if from a bad fairytale spell and can live a healthy life.

Children, rebirth and age are sinister and postive images. Kay thinks Duncan and Mr Mundy "as dark-suited as an undertaker" are an allegory of youth and age (3). Duncan finds a piece of paper "marked in a smudged childish hand: Mabel Alice Mundy twenty dredful curse on you if you read this!" Mr Mundy has a picture of an angel guarding children over his bed. Duncan thinks: "He'd look at that until it was over. ...at the children's large, innocent-spiteful Victorian faces" (152). Fraser claims Mr Mundy is trying to keep Duncan "stuck" (120-1). Realising that he is an adult who doesn't need Mr Mundy's permission, Duncan sneaks off to meet Fraser $(153-154,156)$. Kay reflects on how a boy is rescued during demolition work after a bomb-blast she attends as an ambulance driver: "head-first, as...out of the womb; but rigid, dry, dusty, his hair an old man's" (469). The novel ends: "The dust fell away. The skin beneath was pink, plump, astonishingly smooth" (470). Kay wonders "that something so fresh and so unmarked could have emerged from so much chaos" (470). Metaphorically, the novel suggests that the Victorian era gives birth to the 
twentieth century.

Referencing the Victorian in a novel set circa WWII enables Waters to remain connected to her established audience while investigating a different era, demonstrating the continuity and disconnection from the Victorians of later generations. These Victorian references affect Waters' treatment of homosexuality. Andrew Smith discusses the link between homosexuality and the gothic in Dorian Gray (166-169) and George Haggerty refers to the Queer Gothic (2006) This queer or gay gothic influences the male characters in Night Watch. Waters uses Victorian social and literary conventions to dramatically enhance the tension experienced by the characters towards war and modernity creating the effect of 'Wartime Gothic'.

This can be seen in other works from the WWII period. In The Journals of Denton Welch, Welch's description of his bombed house lends itself to the gothic. The Victorian gothic novel is famous for its grand mansions which appear physically affected by supernatural forces. It is as if a supernatural, not merely violent, force has affected Welch's grand domestic setting:

I went round the corner of the wall and saw a huge mound of earth by the outside-staircase, the fir tree uprooted and tossed away, a hole like a burst blister dug deep into the large bed. Everywhere was earth, on the verandah, on the roof, and glass in huge knives and spears sticking into everything.

I went into the drawing-room, smothered inches deep in debris. But by a miracle nothing broken. Not even the glass lustres standing on the marble chess- table. Little digs and gashes showed on the walnut of the harpsichord; nothing more. (21)

There is a passage with similarity in The Night Watch which contrasts the beauty of high culture with the destruction wrought on it, and nature by a bomb blast, and also contrasting the massively damaged with the miraculously undamaged:

A plane tree thirty feet high had been blasted more or less into 
splinters; houses had lost windows and front doors and slates from their roofs, but were otherwise unmarked. The man and woman, however, had been tossed up into the air. ...The woman had fallen on to the railings on the pavement above - been caught, chest-first, on the blunt tips of the iron spikes...The woman's coat and hat had gone, and her hair was loose about her face; the evening-gloves were smooth and unmarked, still, on her dangling arms. Her silk dress, silvered by the moonlight, was pooled about her on the pavement as though she were curtseying; but the flesh of her bare back bulged where the iron pressed at it from within. (412-3)

Other ghostly remnants of Victorian life and culture appear in the novel. There are references to poet Matthew Arnold (Night Watch, 93) and Sir Arthur Conan Doyle' s Sherlock Holmes (455), music hall song (265), paintings (389) domestic interiors $(4,7-8,252)$, spirituality (10) and even people: the very old woman in the bombed out house who saw Queen Victoria as a little girl (210); Viv's sense of time-travel (58-59). Characters are 'trapped in the past', quasiVictorians. Duncan works in a candle factory (34-35) which is suggestive of past-times. Fraser looks through Duncan: "like a ghost" (156). Kay pacing her attic room "might be a ghost" (4).

The gothic potential of machinery is explored, as in Mary Shelley's seminal gothic text Frankenstein (1818). Prison is a machine for grinding life and time into powder (Night Watch, 204). Kay describes herself in terms of broken clock or wrist watch (1). The dentist's couch on which Viv has her abortion: "looked horrible with the great steel light shining on it, and the trays of instruments all around, the queer machines, the drills, the bottles of gas" (363-4).

V.A.C. Gatrell's The Hanging Tree: Execution and the English People, 17701868, is cited by Waters in her Victorian novel Fingersmith but is also relevant to Night Watch. Mr Mundy escorted men to the scaffold, which he unsuccessfully attempts to humanise in his account to Fraser and Duncan. There is implied sexual sadism in Mr Mundy watching young boys getting flogged (Night Watch, 221) Affinity's prison panoptican appears as Mr Mundy's use of 
spy-holes (205).

Charles Dickens is an influence on Night Watch, just as in Waters' Victorian novels. Characters have Dickensian adventures. Julia says: "II had to lower myself through the fanlight of a house this morning.' Goodness!' said Helen. 'Like Oliver Twist!'” (Night Watch, 209). Fraser takes Duncan on an expedition past old wharehouses, over slippery cobbles, "this queer place." (79). Duncan illogically fears Fraser is mad and has lured him here to murder him (79), like some Fagin-esque character. Duncan's fears are quashed on arrival at a quaint pub "that made Duncan think, at once, of Oliver Twist", but "Inside, the place as not quite so charming as its exterior promised; it had been done up like an ordinary public bar, and there were nonsensical things on the walls, horsebrasses and warming-pans and bellows" (79). The Victorian is ersatz, clearly out of time.

As in earlier Waters novels, characters possess Dickensian descriptive names such as Regie Nigri, Viv's 'black', caddish boyfriend. $(439,443)$. Duncan's surname 'Pearce' suggests his prison martyrdom and his ability to pierce class divisions. The call -up papers of Duncan's friend Alec are addressed to A.J.C. Planer (446), suggesting Jesus Christ and wood, plainly alluding to his sacrificial role as a soldier which he rejects for his suicide plan. Julia Standish suggests she is stand-off-ish, Ursula Waring, a rival that Helen needs to beware of, or is at war with.

Mr Leonard's patients are a Dickensian cast of characters, a parade of the "crooked" woman, the "wounded soldier", the "lame boy" and the "elderly Indian lady with rheumatics" provide a sense of the quantity and variety of humanity. Duncan's workmate Len is a sexually grotesque character, also lame, with a "gypsy eye" (77).

The Night Watch is influenced by the gay gothic. Smith describes how homosexuality has influenced gothic writing, particularly notions of degenerate masculinity and camp (29-33, 150-176). Robert Louis Stevenson's The Strange Case of Jekyll \& Hyde's is an example of the gay gothic, "a fable of fin-de- 
siecle homosexual panic" (Elaine Showalter "Homosexuality and Late Victorian Society" in Boyd and McWilliam, eds., 373). Eve Kosofsky Sedgewick refers to the chase in Frankenstein: "toward a climax that tends to condense the amorous with the murderous." (163 in Smith, Demons, 172). In his pursuit, Alec is like Frankenstein, but he is also reminiscent of the dead Cathy in Emily Bronte's Wuthering Heights, as he taps on his window at night (Night Watch, 156). Heathcliffe in Wuthering Heights is an example of degenerate heterosexual masculinity, who also provides an influence for Duncan and Alec as he is identified with the feminine (in the form of Cathy) and does not fit in with society. "Such constructions [of masculinity]... are united by a shared concern that the middle-class male had become susceptible to moral decline and physical disease." (Smith, 177). Heathcliffe is thought of as an immoral character in his relationship with Cathy, who physically degenerates away from his presence, and the relationship between Victor Frankenstein and his monster is also portrayed as immoral and Frankenstein physically exhausts himself in pursuit of his monster. The Night Watch is similar because Duncan's development is retarded as he remains physically childlike and this is symbolic of the criminally immoral effect Alec has on his life.

This fable involves male hysteria towards emotions between men, middle-class homo-eroticisation of working-class men and the use of sex as a class equaliser (Endnote 2). In The Night Watch this fable is reflected in 'meek Jekyll' Duncan's vicarious identification with Alec's anarchic Hyde (Showalter in Boyd and McWilliam 373-374). Duncan compares Fraser to Alec: “'He was a bit like you... He made things seem exciting. ...You felt - swept along by him."' (Night Watch, 405) Finally, the suicide which ends Jekyll's narrative is the only form of narrative closure thought appropriate to the Gay Gothic, where the protagonist's death is both martydom and retribution (Showalter in Boyd and McWilliam, 376).

Night Watch is influenced by Oscar Wilde. Gay relations in The Night Watch are more sombre and less pastiche-like than in Waters' Victorian novels. Also the difference between The Night Watch and Wilde's writing is the squalid settings of Waters' novel, the lack of beauty in prison, bomb site and suburbia. As I have 
argued in Tipping the Velvet, but it is equally applicable here, Linda Dowling in Hellenism and Homosexuality in Victorian Oxford (1994) notes that during his trial, Wilde defined his relationships with other men as corresponding to the Hellenic intellectual ideal, as physical relationships were illegal (2-3) (Endnote 3). In The Night Watch the relationship between Duncan Pearce and Robert Fraser is mostly depicted as an intellectual and emotional one, because Fraser is heterosexual (120). The relationship between Duncan and "boyfriend" Alec is never described physically. Duncan, in response to Fraser claims that Alec wasn't his boyfriend, that they had an intellectual friendship based on them being outsiders from working class culture (403-4). Fraser asks Duncan to share his bed because he is frightened during the bombing, but they go to sleep embracing (411) rather than engaging sexually.

Wilde's Christian transformation of homosexuality (Smith, 159-163) should also be considered in relation to Night Watch characters. Elderly homosexual $\mathrm{Mr}$ Mundy's commitment to Christian Science cures for his physical suffering may have a Wildean subtext. In De Profundis, the last work published in Wilde's lifetime, which he wrote in prison for (homosexual) gross indecency, he introduces ideas of Christian suffering as a parallel and as a source of redemption for his own mortification. According to Smith "by introducing the model of a passive Christ-like body (one which reflects on the convict's disempowerment) he constructs an alternative version of masculinity" (163). This has parallels with the alternative versions of masculinity exhibited by characters in The Night Watch. Alec's rejection of warfare, subsequent suicide, and what Smith refers to as the imprisonment and mortification of the body by prison conditions, like that experienced by Duncan and Fraser (and see Kosofsky Sedgewick's Epistemology of the Closet and Wilde's De Profundis, in Smith, 159-163).

Wilde's Dorian Gray is also part of the gay gothic literary traditon. In The Night Watch, as in Dorian Gray, an implicitly gay relationship leads to the downfall of its protagonists (Endnote 4). As lesbian society was not visible or stigmatised to the same degree in Victorian society, The Night Watch's lesbian characters are not subject to the same treatment. Duncan is presented as a Dorian Gray double. 
Viv thinks: "All he put us through, look, and there's not a bloody mark on him!" (30). The evil, old Mr Mundy physically deteriorates as Duncan renews his relationship with Fraser (149). Duncan takes the blame for Alec's decision, as Lord Henry Wooton for Dorian Gray or Wilde for Douglas (Dowling, 147-148). Dowling writes:

As the corrupting instructor of Dorian Gray, Lord Henry Wotton represented, Wilde knew, all that the world imagined Wilde to be in his relation to Douglas. Yet the grotesque truth of their actual relationship would always remain that the "corruption" and fatal influence of "personality" had in fact worked all the other way. It was not Wilde who had ruined the younger man. It was instead the younger man who had ruined Wilde with "an unintellectual friendship, a friendship whose primary aim was into the creation and contemplation of beautiful things," a bond "intellectually degrading to me" destroying the conditions for his art... (147-8)

Unlike Alec, Fraser's influence on Duncan is the opposite of corrupting, as he seeks to raise his working class friend by offering himself as a mentor. "Dorian Gray also causes the suicides of a number of young men and then kills himself. ...Death is the only solution to the: "illness" of homosexuality" (Veeder in Showalter in Boyd and McWilliam, 376). Smith also reflects on the Gothic nature of Dorian Gray and the conflict between the virtue of questioning moral conventions, while still having moral constraints, the difficulty is where to place them (166-169). This is applicable to The Night Watch as for Alec, killing others is murder, but killing himself is acceptable.

\section{Conclusion}

The Night Watch is the culmination of Waters' use of Victorian influences, paradoxically, within a novel set in a later era, WWII. The combination of these often conflicting influences makes it the most complex of Waters' novels. Waters manages to sustain this tension creatively, and the Victorian aspects are blended into the modern by emphasising historic continuity. The heightened dramatism of Victorian gothic is an appropriate literary mode for expressing the 
heightened unnaturalness of wartime. Waters' genius lies in convincing the reader that this apparently counterintuitive cross-pollination is a natural choice.

\section{Endnotes}

1. From a conversation with my grandmother, Bobby Robinson, 2007.

2. See Paul Zablocki and John Perry, "Novel as Homotext: A Gay Critical Approach to Narrative." in Boyd and McWilliam, eds., (373) and Heath, Stephen "Psychopathia Sexualis: Stevenson's Strange Case." and Weeks, Jeffrey, Sex, Politics, and Society. in Boyd and McWilliam, eds., (372-373, $375)$.

3. Linda Dowling writes in Hellenism and Homosexuality in Victorian Oxford:

The power and originality of Wilde's appeal to a Hellenic ideal lie in the way it exploits this space, outlining in irresistible terms an idea of male love as a mode of inward erotic orientation and sensibility wholly distinct from mere genital activity, and yet also a mode so far unreduced to the new pathological models of medical and psychiatric science. $(2-3)$

4. The Night Watch echoes the Victorian morality tale. A 'queer' relationship, outside the bounds of working-class society, leads Duncan to prison, harm to his family and the clutches of quasi paedophile $\mathrm{Mr}$ Mundy. This becomes a melodrama, a drama with a happy ending, when his middle class cell mate is a saviour of sorts. 


\section{Works Cited}

Anonymous. The Lustful Turk, A Man and His Maid. Cited by Bronski, Michael. "Early Lesbian Porn?" Gay Community News, 9.41 (1982), p. 1. Retrieved April 21, 2008, from Academic Research Library database. (Document ID: 1103051021).

Anonymous. The Pearl: A Journal of Facetiae and Voluptuous Reading. (187980). New York: Grove, 1968.

Ashbee, Henry Spencer (Pisanus Fraxi): Index Librorum Prohibitorum: being Notes Notes Bio - Biblio - Icono - graphical and Critical, on Curious and Uncommon Books (London, 1977); Centuria Librorum Absconditorum being Notes Bio -Biblio-Icono-graphical and Critical and Uncommon Books (London, 1879); and Catena Librorum tacendorum: being Notes Bio- Biblio- Icono- graphicical and critical, on Curious and Uncommon Books (London, 1885). Also see Ashbee, above, for publishing details of The Festival of the Passions, Memoirs of a Woman of Pleasure, The Curtain Drawn Up, The Bagnio Miscellany, The Birchen Bouquet, and The Lustful Turk. Cited by Waters, Sarah, Fingersmith. London: Virago, 2003.

Atherton, James. The Books at the Wake. Carbondale: Southern Illinois University Press, 1974.

Auerbach, Nina. "Before the Curtain." The Cambridge Companion to Victorian and Edwardian Theatre. Ed. Kerry Powell. Cambridge: Cambridge University Press, 2004.

Bartlett, Neil. Who Was That Man? A Present for Mr Oscar Wilde. London: Serpent's Tail, 1988.

Bell, Barbara. Just Take Your Frock Off. Ed. Brighton Ourstory Project. Brighton: Ourstory Books, 1999.

Boyd, Kelly and McWilliam, Rohan, eds. The Victorian Studies Reader. Oxford: Routledge, 2007.

Bronski, Michael. “Early Lesbian Porn?” Gay Community News, 9.41 (1982), p. 1. Retrieved April 21, 2008, from Academic Research Library database. (Document ID: 1103051021).

Bronte, Emily. Wuthering Heights. (1847). London: David Campbell, 1991.

Collins, Wilkie. The Woman in White. (1860). London: Penguin, 1999. 
---. The Law and the Lady. (1875). The Works of Wilkie Collins. New York: Peter Fenelon Collier, ca. 1900.

---. The Woman in White. (1860). Harmondsworth: Penguin, 1985 in Smith, 126.

Craik, Dinah Mulock. A Life for a Life. (1859). London and Newcastle-onTyne: Walter Scott Publishing Co., 1903.

Davis, Tracy C. "Actresses as Working Women: Their Social Identity in Victorian Culture." Gender and Performance. Eds. Tracy C. Davis and Susan Bassnett. London and New York: Routledge, 1991.

Dickens, Charles. Bleak House. (1853). Harmondsworth: Penguin, 1985.

Dickens, Charles. David Copperfield. (1850). Oxford: Oxford University Press, 1999.

Dickens, Charles. Great Expectations. (1861). Harmondsworth, Middlesex: Penguin, 1965.

Dickens, Charles. Oliver Twist. (1839). London: Signet Classics, 1961.

Dickens, Charles. Oliver Twist. (1839). London: David Campbell, 1992.

---. "On Duty with Inspector Field.” (1851). Household Words, 14 June.

Dowling, Linda. Hellenism and Homosexuality in Victorian Oxford. Ithaca and London: Cornell University Press, 1994.

Doyle, Arthur Conan. The Adventures of Sherlock Holmes. (1892). Harmondsworth: Penguin, 1981.

Dublin University. "Unsigned Review of Wilkie Collins' The Woman in White." Dublin University Magazine February lvii. (1861): xxxii.

Faulk, Barry J. Music Hall and Modernity: The Late Victorian Discovery of Popular Culture. Athens, Ohio: Ohio University Press, 2004.

Gates, Barbara T. Victorian Suicide: Mad Crimes and Sad Histories. Princeton: Princeton University Press, 1988.

Gatrell, V.A.C. The Hanging Tree: Execution and the English People, 17701868. Oxford: Oxford University Press, 1994.

Heath, Stephen “Psychopathia Sexualis: Stevenson's Strange Case.” Critical Quarterly 28 (1986).

Hollingworth, Keith The Newgate Novel 1830-1847: Bulwer, Ainsworth, Dickens and Thackeray. Detroit: Wayne State University Press, 1963.

Hurley, Kelly. The Gothic Body: Sexuality, Materialism, and Degeneration at the Fin De Siecle_Cambridge: Cambridge University Press, 1996. 
Jann, Rosemary. "Sherlock Holmes Codes the Social Body." English Literature History 57.3 (1990): 685-708, 693.

Jay, Karla "A Chaste Take on Those Naughty Victorians." The Gay \& Lesbian Review Worldwide 9.3 (2002): 39.

Keynes, Randal. Annie's Box: Charles Darwin, His Daughter and Human Evolution. London: Fourth Estate, 2001.

---. "Epistemology of the Closet." London: Harvester Wheatsheaf, 1991.

Lycett, Andrew. " Erotic Heaven." Review of The Erotomaniac: the Secret Life of Henry Spencer Ashbee. New Statesman 14.647 (2001): 57. $<$ http://www.newstatesman.com/200103120050>

"Mass Observation Studies." Sussex, 1937-1955. Mass Observation Archive. University of Sussex 2007. <http://www.massobs.org.uk>.

Mayer, David. "Encountering Melodrama." The Cambridge Companion to Victorian Literature. Ed. Kerry Powell. Cambridge: Cambridge University Press, 2004, pp 145-63.

Melville, Joy. Mother of Oscar: The Life of Jane Francesca Wilde. London Allison \& Busby, 1999.

Milbank, Alison. Daughters of the House: Modes of the Gothic in Victorian Fiction. Basingstoke: Macmillan, 1992.

Moers, Ellen. Literary Women. London: Women's Press, 1978.

National Archives: "Lesbian and Gay History Getting out There." News Release. $21 \quad$ Feb. 2006. 26 Mar. 2008. $<$ http://www.cityoflondon.gov.uk/Corporation/media_centre/files2006/ out_there.htm >.

Nead, Linda. "The Meaning of the Prostitute." Myths of Sexuality: Representations of Women in Victorian Britain. Eds. Kelly Boyd and Rohan MacWilliam. Oxford: Basil Blackwell, 1988, pp 349.

Nord, Deborah Epstein. "Vitiated Air" the Polluted City and Female Sexuality in Dombey and Son and Bleak House." Sexualities in Victorian Britain. Eds. Andrew H. Miller and James Eli Adams. Bloomington, IN and Indianapolis: Indiana University Press, 1996, pp. 38-59.

O'Gorman, Francis, ed. The Victorian Novel. Oxford: Blackwell, 2002.

Pearsall, Phyllis. Women at War. Aldershot, Hants.: Ashgate Editions, 1990.

Powell, Kerry, ed. The Cambridge Companion to Victorian and Edwardian Theatre. Cambridge: Cambridge University Press, 2004. 
Presley, John Woodrow. "Finnegan's Wake, Lady Pokingham, and Victorian Erotic Fantasy." Bowling Green: Journal of Popular Culture. 30.3 (1996): 67-80.

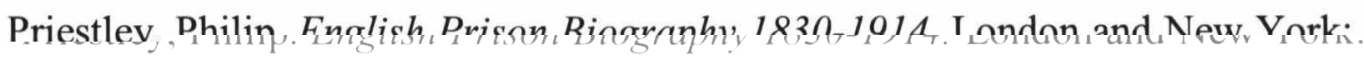
Methuen, 1985.

Sala, George Augustus. Daylight and Gaslight. London: Chapman and Hall, 1859.

Saturday Review; December 5, 1874.

Sedgewick, Eve Kosofsky. Between Men: English Literature and Male Homosocial Desire. New York: Columbia University Press, 1985.

Sheridan, Dorothy, ed. Wartime Women: A Mass Observation Anthology 19371945. London: Phoenix, 2000.

Showalter, Elaine. "Homosexuality and Late Victorian Anxiety." Sexual Anarchy: Gender and Culture at the Fin-De-Siecle. New York: Viking Penguin, 1990, in Boyd, Kelly and McWilliam, Rohan. Eds. The Victorian Studies Reader. Oxford: Oxford University Press, 2007, pp 370-79.

Smith, Andrew. Victorian Demons: Medicine, Masculinity and the Gothic at the Fin-De-Siecle. Manchester: Manchester University Press, 2004.

Sontag, Susan. "Notes on Camp", Against Interpretation. New York: Dell, 1966, pp 275-292.

Stevenson, Robert Louis. The Strange Case of Dr Jekyll and Mr Hyde (1886) in The Strange Case of Dr Jekyll and Mr Hyde and Other Stories. Ed. Jenni Calder. Harmondsworth, Penguin, 1984.

Sutherland, John. "Wilkie Collins and the Origins of the Sensation Novel", Dickens Studies Annual 20 (1991), 244-58.

Sweet, Matthew. "Introduction." The Woman in White. London: Penguin, 1999.

Symons, Arthur. "A Spanish Music-Hall." Cities and Sea-Coasts and Islands. New York: Brentano's, 1919.

Veeder, William. "Children of the Night: Stevenson and Patriarchy." Dr. Jekyll and Mr. Hyde after One Hundred Years. Chicago: University of Chicago Press, 1988.

Vicinus, Martha. "Helpless and Unfriended: Nineteenth Century Domestic Melodrama." When They Weren't Doing Shakespeare: Essays on Nineteenth Century British and American Theatre. Eds. Judith L. 
Fisher and Stephen Watt. Athens University of Georgia Press, 1989, pp 174-86.

Waters, Sarah. Affinity. London: Virago, 2000.

---. Fingersmith. London: Virago, 2003.

---. The Night Watch. London: Virago, 2006.

---. Tipping the Velvet. London: Virago, 1999.

Weeks, Jeffrey. Sex, Politics, and Society. New York and London: Longman, 1981.

Welch, Denton. The Journals of Denton Welch. De-la-Noy, Michael, Ed. 1952. London: Allison \& Busby, 1984.

Wells, H.G. The Invisible Man. Leipzig: Bernard Tauchnitz, 1898.

Wheeler, Michael. English Fiction of the Victorian Period. London: Longman, 1985.

Wilde, Oscar. "De Profundis." (1897). The Complete Works of Oscar Wilde. Ed. G.F. Maine. London: Collins, 1992.

---. The Picture of Dorian Gray. (1890). Oxford: Oxford University Press, 1981.

---. The Picture of Dorian Gray. (1890). Harmondsworth: Penguin, 1985.

Wilson, Keith. "Music-Hall London: The Topography of Class Sentiment." Victorian Literature and Culture 23 (1996): 23-25, 57.

Wood, Ellen (Mrs Henry Wood). East Lynne. (1861). New York: Broadview Press, 2000.

Wood, Ellen (Mrs Henry Wood). East Lynne: A Domestic Drama in a Prologue and Four Acts. Adapted from Mrs Wood's novel. By T.A. Palmer (1875).

Wood, Jane. Passion and Pathology in Victorian Fiction. Oxford: Oxford University Press, 2001.

Zablocki, Paul and Perry, John. "Novel as Homotext: A Gay Critical Approach to Narrative." Unpublished thesis. Princeton University, 1987.

\section{Bibliography}

Austen, Jane. Northanger Abbey. (1818). London: David Campbell, 1992.

Booth, Michael. "Comedy and Farce." The Cambridge Companion to Victorian and Edwardian Theatre. Ed. Kerry Powell. Cambridge: Cambridge University Press, 2004, 129-144. 
Bratton, Jacky. New Readings in Theatre History. Cambridge, UK and New York: Cambridge University Press, 2003.

Collins, Wilkie. Basil. (1852). Oxford: Oxford University Press, 1989.

Corbett, Mary Jean. "Performing Identities: Actresses and Autobiography." The Cambridge Companion to Victorian and Edwardian Theatre. Ed. Kerry Powell. Cambridge: Cambridge University Press, 2004, pp 10926.

Davis, Jim and Emeljanow, Victor. "Reflecting the Audience: London Theatregoing, 1840-1880." Studies in Theatre History \& Culture. Ed. Thomas Postlewait. Iowa: University of Iowa Press, 2001.

Davis, Jim and Victor Emeljanow. "Victorian and Edwardian Audiences." The Cambridge Companion to Victorian and Edwardian Theatre. Ed. Kerry Powell. Cambridge: Cambridge University Press, 2004, pp 93108.

Dickens, Charles. Little Dorrit. (1857). London: David Campbell, 1992.

Dickens, Charles. Nicholas Nickleby. (1839). Oxford: Oxford University Press, 1998.

Dickens, Charles. Our Mutual Friend. (1865). London: David Campbell, 1994.

Faulk, Barry J. “'Spectacular' Bodies: Tableaux Vivants at the Palace Theatre.” Music Hall and Modernity: The Late Victorian Discovery of Popular Culture. Ed. Barry J Faulk. Ohio: Ohio University Press, 2004, pp 142187.

Faulk, Barry J. "Tales of the Culture Industry." Music Hall and Modernity: The Late Victorian Discovery of Popular Culture. Ed. Barry J Faulk. Ohio: Ohio University Press, 2004, pp 111-41.

Grass, Sean Christopher. "The Self in the Cell: Narrating the Victorian Prisoner." The Pennsylvania State University (1999). Retrieved April 21, 2008, from ProQuest Digital Dissertations database. (Publication No. AAT 9960588).

Gregory, Phillipa. The Other Boleyn Girl. London: Harper Collins, 2001.

Haggerty, George E. Queer Gothic. Urbana and Chicago. University of Illinois Press, 2006.

Hurley, Kelly. The Gothic Body: Sexuality, Materialism, and Degeneration at the Fin De Siecle. Cambridge: Cambridge University Press, 1996. 
James, Henry. The Turn of the Screw. (1898). Ed. Lloyd Smith, Allan. London: J.M. Dent; [Rutland], Vermont: Charles E. Tuttle, c1993.

James, Louis. The Victorian Novel. Oxford: Blackwell, 2006.

Janzen, Lorraine. "Modern Markets for Goblin Market." Victorian Poetry 32.34 (1994): 249.

Rosetti, Christina. Goblin Market. (1862). Middleton, Sussex: Silver Unicorn Press, 1931.

Sloan, John. Oscar Wilde. Oxford: Oxford University Press, 2003.

The Victorian Web. <http://www.victorianweb.org>. 27 April 2008.

White, Jerry. London. London in the Nineteenth Century. London: Jonathan Cape, 2007.

Wilson, A.N. The Victorians. New York: W. W. Norton \& Company, 2003. 